\title{
6 Simulations of the pandemic propagation patterns on the example of Poland and Ukraine
}

\author{
Pawet Dykas, Katarzyna Filipowicz, \\ Olesia Chornenka, Oleksij Kelebaj, and \\ Tomasz Tokarski
}

\subsection{Introduction}

The COVID-19 pandemic in Poland, as well as in Ukraine, started in March 2020. The first measures to limit the spread of the SARS-CoV-2 virus were implemented as early as the beginning of 2020. In Poland, preventive measures were introduced well before the first case of the SARS infection was registered (4 March 2020, in Zielona Góra) and the first person died because of it (14 March 2020). As early as 25 January 2020, Warsaw Chopin Airport introduced special security procedures for passengers arriving from China (Lotnisko Chopina w Warszawie, 2020). On 31 January 2020, the National Institute of Hygiene in Poland began laboratory testing of people with suspected SARS infection (Medonet, 2020). In Ukraine, on the other hand, the National Security and Defence Council at its meeting on 25 February 2020 decided to introduce temperature screening for all persons entering the territory of Ukraine (Ukrinform, 2020), and the public was informed about the risks and health hazards related to this virus infection and the recommended precautions.

In Ukraine, the first person infected with SARS-CoV-2 was registered on 3 March 2020, in the Chernivtsi region of western Ukraine, and the first death caused by the virus was registered on 13 March 2020 (Indexminfin, 2021). Following the KMU Decree, ${ }^{1}$ the so-called lockdown (defined as a national quarantine) was introduced in Ukraine on 12 March 2020. The decree provided for the introduction of a quarantine in the entire territory of Ukraine from 12 March to 3 April 2020 involving mainly a number of restrictions including, among others, the closure of all educational institutions and a ban on all mass gatherings for more than 200 people $^{2}$ (KMU, 2020a).

1 KMU Decree no 211 of 11 March 2020.

2 With the exception of the meetings necessary to ensure the work of public authorities and local governments. 
The situation was very similar in Poland, where the epidemiological status $^{3}$ was introduced 16 days after the first infection (Serwis Rzeczypospolitej Polskiej, 2020a). In Poland, the following measures were introduced: an obligatory 14-day quarantine for persons entering the territory of Poland, ${ }^{4}$ a ban on the circulation of certain protective goods, restrictions on the functioning of certain educational and cultural institutions and workplaces, and a ban on gatherings for more than 50 people. As of 25 March 2020, when the total number of infected people fluctuated around 1,050, further restrictions were introduced (Serwis Rzeczypospolitej Polskiej, 2021). Despite these restrictions, the number of infections continued to rise dramatically, with 2,311 infections and 33 deaths recorded in Poland at the end of March, so the government introduced further restrictions as of 1 April 2020 under which, among others, persons under 18 were not allowed in public spaces without an adult guardian, parks, forests and beaches were closed to visitors and the activity of hairdressing and beauty salons was suspended. In shops and service outlets, there were restrictions on the number of customers served at the same time.

As part of Ukraine's national quarantine, border checkpoints were partially closed (only 49 out of 219 remained open), while educational and cultural institutions were forced to operate online. As of 16 March 2020 (when there were seven infected individuals in Ukraine), a ban on foreigners entering the territory of Ukraine was introduced. On the following day, international air, bus and rail traffic was suspended. Similar restrictions were applied on 18 March within Ukrainian regions and cities, preventing people without their own transport from travelling outside their places of residence. Due to the increasing rate of infections in Ukraine (on 1 April, the total number of infections in Ukraine amounted to 794 and 20 people died), on 2 April the Ukrainian government adopted another decree, ${ }^{5}$ which extended the national quarantine until 24 April 2020 and introduced even more restrictions for Ukrainian citizens (e.g. the restriction of movement in groups of more than two persons, obligatory covering of the mouth and nose in public places, a ban on visiting parks and forests, the suspension of the activity of catering and sports facilities). Just like in Poland, administrative and criminal liability for non-compliance with quarantine rules was introduced (VRU, 2020).

After four weeks of quarantine in Poland, the total number of infected persons was 9,593 and 380 persons died due to SARS-CoV-2 infection. At this time, the lockdown easing started as part of stage one out of four stages of restriction relaxation. The number of customers in shops was increased while parks and forests were opened. The next stage involved the opening

3 Pursuant to the Resolution of the Health Minister of 20 March 2020.

4 With the exception of some categories of people.

5 Decree no 255 of 2 April 2020. 


\section{Pawet Dykas et al.}

of shops with construction materials on weekends as well as hotels and cultural institutions. In the third stage, hairdressing and beauty salons, catering facilities and shops in shopping malls were opened. ${ }^{6}$ Sporting events could be attended by no more than 50 people, ${ }^{7}$ and nurseries and kindergartens, as well as schools for children from classes 1-3, were opened. The final stage of the quarantine abolition involved the opening of sports and recreational facilities, as well as theatres and cinemas (Serwis Rzeczypospolitej Polskiej, 2020b).

In April, the Health Ministry of Ukraine announced its intention to lift some of the restrictions. Just like in Poland, the process was extended over several stages. At the beginning of May 2020, when the total number of infected persons was around 15 thousand, the Ukrainian government introduced the first stage of the national quarantine relaxation, which resulted in parks and forests being opened and non-food shops, dental and cosmetology surgeries resuming their economic activity (Glavcom, 2020). On 22 May 2020, when the total number of infections was 20,148, people could resume using public transport (KMU, 2020b). Further steps in the quarantine abolition in Ukraine involved the opening of cultural and sports institutions in June 2020, and on 15 June 2020 international air traffic was partially restored (Unian, 2020).

The total number of infected persons in Poland at the end of May 2020 fluctuated around 24,000 (more than 1,000 deaths were also registered), and as early as the end of August the number had almost tripled and amounted to 67,372 persons (and 2,039 deaths). Although in the first two months of the summer season the situation in Poland relatively normalized and the daily number of newly infected persons fluctuated around 350, by August this number had almost doubled. In September, the rate of infections increased even more and at the end of the month the number of new infections was over 1,300 per day.

The situation was similar in Ukraine, with an average of 700 newly infected persons per day (and 15 deaths per day) in June and 800 persons per day (and 17 deaths per day) in July. In August, however, the number of infected persons began to increase dramatically and by the end of the month already exceeded 2,000 persons per day, which is why the Ukrainian government decided to introduce another restriction, i.e. a ban on entry for foreigners from 28 August 2020 to 28 September 2020 (MSZU, 2020).

In autumn, both Poland and Ukraine reported increasing infection rates. In October 2020, the number of newly infected persons in Poland fluctuated around 8,500 persons and in Ukraine the number was 6,000. The number of deaths per day, in both countries, averaged around 100, so by the end of October the total number of infections in Ukraine was 387,481 and there

6 With sanitary restrictions.

7 Without the participation of the audience and in open space. 
had been 7,196 deaths, while in Poland these numbers were (respectively) 362,731 and 5,631 .

Due to the dramatically rapid increase in the number of infections, ${ }^{8}$ the governments of both countries were forced to introduce further restrictions. In Ukraine it was done in November 2020 when the Ukrainian government introduced the so-called weekend quarantine from 13 November to 30 November 2020 (KMU, 2020c). The restrictions primarily involved a ban on services provided by cultural institutions, sports and catering facilities during the weekend. However, as the Ukrainian government later admitted, the weekend quarantine did not have the desired effect and by the end of November 2020, the total number of infected persons was 732,625.

In Poland, the aforementioned restrictions took effect as of 24 October 2020. Restrictions on movement and the operation of schools (including universities) were reintroduced, the business activity of sports venues and catering facilities was suspended (allowing only takeaway options) and the number of customers in shops was limited (Portal miasta Gdańsk, 2020).

At the end of the period analyzed in this chapter, i.e. on 3 December 2020 , the total number of infected persons was 772,760 and 12,960 people had died in Ukraine, while for Poland these numbers were, respectively, $1,028,610$ and 18,828. Due to the rapid rate of SARS-CoV-2 propagation and the high risk of health system collapse, in early December the governments of both countries announced the possibility of introducing another lockdown during the holiday season. According to the announcement of December 2020, it was to last until the end of January 2021.

\subsection{The epidemiological model and calibrations of its parameters}

The empirical analyses of the epidemiological situation in Poland and Ukraine in Chapter 6 are based on the extended SIR (Susceptible-InfectedRemoved) model of Kernack, McKendrick (1927), which was presented in Chapter 5. This model is based on the conjunction of the following increments:

$$
\left\{\begin{array}{l}
\Delta S_{t}=-\beta \kappa_{t} S_{t-1} I_{t-1}-\delta_{t} \varepsilon \rho \pi S_{t-21} \\
\Delta I_{t}=\beta \kappa_{t} S_{t-1} I_{t-1}-\gamma I_{t-1} \\
\Delta H_{t}=\gamma h I_{t-1} \\
\Delta D_{t}=\gamma(1-b) I_{t-1} \\
\Delta P_{t}=\delta_{t} \varepsilon \rho \pi S_{t-21}
\end{array}\right.
$$

8 In late October, the number of cases per day exceeded 20,000 people in Poland and 8,000 in Ukraine. 
where:

$S_{t}$ - percentage of uninfected individuals,

$I_{t}$ - percentage of infected individuals,

$H_{t}$ - percentage of convalescent individuals,

$D_{t}$ - percentage of deaths,

$P_{t}-$ percentage of the vaccinated population.

Parameter $\beta$ describing the rate of the epidemic spread was chosen numerically, so that the proportion of the population determined by the model on day 275 of the epidemic was equal to the empirical value of this proportion on 3 December 2020. As a result of numerical analyses, the value of $\beta$ for Poland was adopted at the level of 0.1015 and for Ukraine at 0.1053 . Just like in Chapter 5, it is assumed that the average duration of an infection caused by SARS-CoV-2 is 14 days, hence the value of parameter $\gamma$ obtained is 0.071429. In numerical analyses, it is assumed that the average percentage of convalescent persons $h$ is 0.985 , which means that the mortality rate of infected persons is at the level of $1.5 \%$. In further deliberations, it is also assumed that on the first day of the epidemic the proportion of infected persons was one per one million inhabitants.

This model introduces the indicator describing the degree of socioeconomic activity. This kind of approach can be found in the works of Bärwolff (2020) or Atkeson (2020), among others. In this chapter, it is assumed that the socioeconomic activity index $\kappa_{t}$ in both countries is achieved by means of the following relationship:

$$
\kappa_{t}=\theta \cdot \eta_{t},
$$

where variable $\eta_{t}$ is a dichotomous variable taking the value of 1 when restrictions are introduced on a given day and 0 when there are no socioeconomic life restrictions on a given day. In Poland, the value of parameter $\theta$ was assumed at the level of 0.804 ; in Ukraine it was 0.792 . Just like in the case of parameter $\beta$, the values of parameter $\theta$ were chosen in such a way that the proportion of infected individuals resulting from the model coincided with the empirical proportion.

In the model described by equations (6.1-6.5), dichotomous variable $\delta_{t}$ takes the value of 1 when a vaccination programme was introduced on a given day and 0 when there were no vaccinations. In further analyses, it is assumed that in Poland vaccination starts on 28 December 2020, i.e. on day 300 of the pandemic, and in Ukraine on day 335 of the pandemic. It is also assumed that in Poland $50 \%$ of the population declares the willingness to be vaccinated $(\rho=0.5)$, while for Ukraine this indicator is $60 \%(\rho=0.6)$, but in the scenario analysis it is assumed that the values of this parameter in both countries deviate by $\pm 50 \%$ from the adopted values. Furthermore, in further considerations it is assumed that vaccine efficacy $\varepsilon$ is $95 \%$ and daily vaccination rate $\pi$ for those declaring their willingness to be vaccinated equals $2 \%$ in both countries. 


\subsection{Results of numerical simulations}

Numerical simulations were conducted in four scenarios. Scenario one, called the baseline scenario, assumes that the epidemic spreads naturally, without any state intervention. In subsequent scenarios, it is assumed that the state introduces restrictions on socioeconomic life. In scenario A, it is assumed that restrictions are maintained until the proportion of infected individuals falls below half of the empirical proportion on day 275 of the epidemic. Scenario B assumes that the lockdown restrictions are gradually lifted starting from day 321 after the outbreak; furthermore, the rate of restriction easing in this scenario is $5 \%$ per week. In scenario C, all restrictions will be lifted on day 321 of the epidemic. Each scenario includes four variant options. In variant 1 there is no vaccination, while the subsequent variant options include a vaccination programme. In variants $2-4$, it is assumed that in the case of Poland $50 \%, 75 \%$ and $25 \%$ of the population declare their willingness to be vaccinated (respectively). In the case of Ukraine, the proportions are $60 \%, 90 \%$ and $30 \%$.

\subsubsection{Results of numerical simulations for Poland}

The baseline scenario assumes that the pandemic spreads freely, without any government intervention. This scenario will serve as a reference for the other scenarios. In the hypothetical situation considered, the peak of the epidemic would occur on day 311 since its beginning (i.e. about 8 January $2021^{9}$ ) with the maximum proportion of infected individuals at the level of $4.94 \%$. The cumulative death rate would be $7.9 \%$, i.e. about 303,000 people ${ }^{10}$ would die in Poland. The epidemic in Poland would end 968 days after its outbreak and convalescent individuals would make $52.12 \%$ of the population (cf. Figure 6.1).

In scenario $\mathrm{A}$, it is assumed that socioeconomic life restrictions will be maintained until the proportion of infections falls below $4.73 \%$ (i.e. half of the empirical percentage on day 275 of the epidemic). In option $A_{1}$ (without a vaccine), the lockdown would end on day 544 of the epidemic, i.e. on 29 August 2021. The maximum proportion of infections would be recorded on day 363 of the epidemic and it would be equal to $1.24 \%$ (i.e. 3.7 percentage points lower than in the baseline scenario). After the lifting of restrictions, the proportion of infections would rise again slightly to the level of $7.21 \%$ on day 672 of the epidemic, decreasing in the following months (on day 1,500 of the epidemic the number of infected people in Poland would be

9 It is assumed that the first day of the epidemic is the day of the first confirmed case of the virus infection, i.e. 4 March 2020 in Poland.

10 Calculated on the basis of the data provided by the Chief Statistical Office (GUS). According to GUS, Poland's population in September 2020 was 38,351,000 people: https://stat.gov .pl/podstawowe-dane/. 


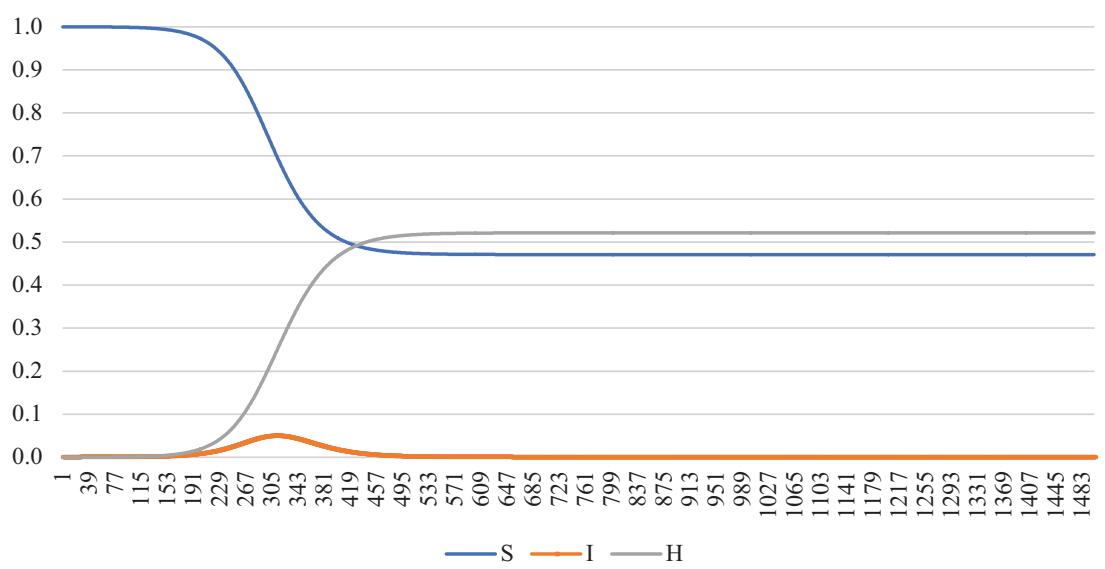

Figure 6.1 Trajectories of proportions $S, I$ and $H$ for the baseline scenario. Source: the author's own study.

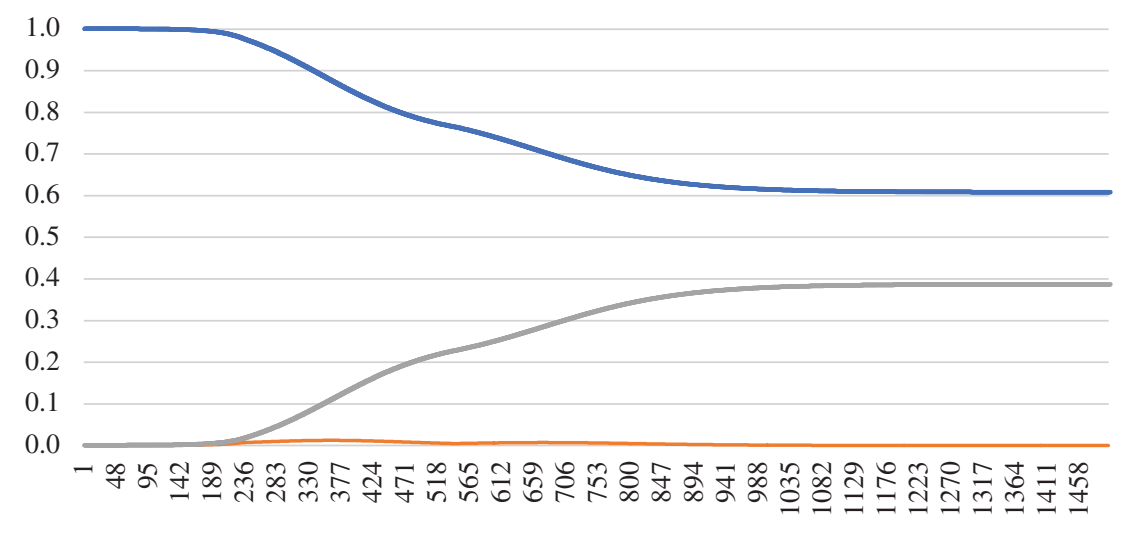$$
-\mathrm{S}-\mathrm{I}-\mathrm{H}
$$

Figure 6.2 Trajectories of proportions $S, I$ and $H$ for scenario $\mathrm{A}_{1}$ (without a vaccine). Source: the author's own study.

about 313$)$. In this scenario, $38.7 \%$ of the Polish population would make the group of convalescents. The cumulative death rate would amount to $5.9 \%$, i.e. about 226,000 persons would die (about 77,000 fewer than in the baseline scenario, cf. Figures 6.2 and 6.6, Table 6.1).

The next three variants of scenario $A\left(A_{2}-50 \%\right.$ vaccinated, $A_{3}-75 \%$ vaccinated, $A_{4}-25 \%$ vaccinated) focus on the spread of the epidemic in the situation when the vaccination process has begun. It is assumed that on 18 January 2021 (i.e. on day 321 of the epidemic), the first individuals with post-vaccination immunity will appear in the population (thus reducing 
Table 6.1 Minimum proportion of uninfected persons $\left(\mathrm{S}_{\mathrm{m}}\right)$, maximum proportion of infected persons $\left(\mathrm{I}_{\mathrm{M}}\right)$, maximum proportion of vaccinated persons $\left(\mathrm{P}_{\mathrm{M}}\right)$, maximum proportion of convalescents $\left(\mathrm{H}_{\mathrm{M}}\right)$ and the deceased $\left(\mathrm{D}_{\mathrm{M}}\right)$, day of the epidemic with the highest number of infections $(\mathrm{T})$ for scenario $\mathrm{A}$ with different variants

\begin{tabular}{lllllll}
\hline variants & $S_{m}$ & $I_{M}$ & $H_{M}$ & $D_{M}$ & $P_{M}$ & $T$ \\
\hline $\mathrm{A}_{1}$ & 0.6077 & 0.0124 & 0.3865 & 0.0059 & 0 & 362 \\
$\mathrm{~A}_{2}$ & 0.2567 & 0.0121 & 0.2204 & 0.0034 & 0.5195 & 342 \\
$\mathrm{~A}_{3}$ & 0.1537 & 0.0120 & 0.1957 & 0.0030 & 0.6476 & 338 \\
$\mathrm{~A}_{4}$ & 0.4176 & 0.0122 & 0.2665 & 0.0041 & 0.3119 & 349 \\
\hline
\end{tabular}

Source: the author's own study.

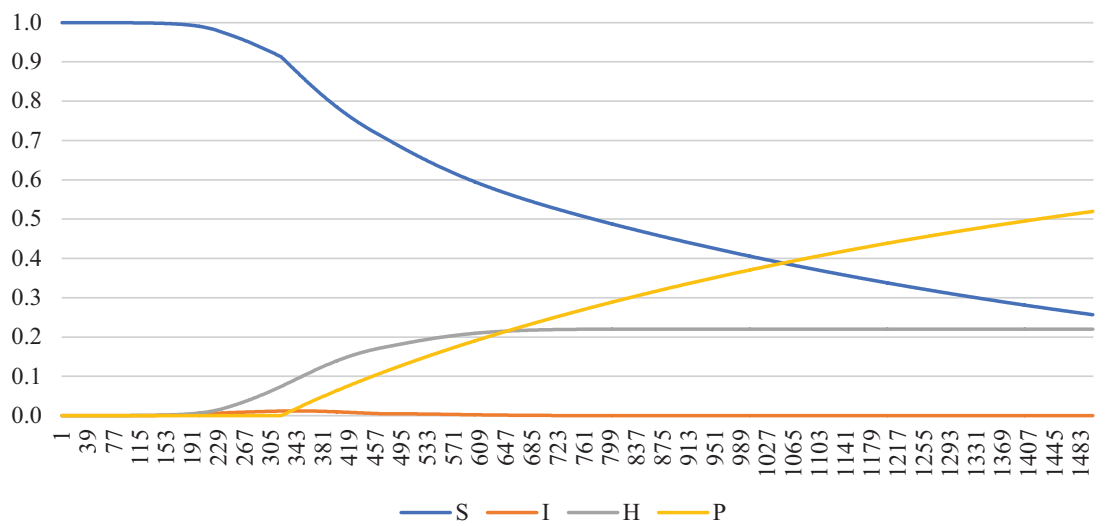

Figure 6.3 Trajectories of proportions $S, I, H$ and $P$ for scenario $\mathrm{A}_{2}(50 \%$ of the population vaccinated). Source: the author's own study.

the proportion of the population at the risk of infection). In scenario $\mathrm{A}_{2}$ it is assumed that $50 \%$ of the Polish population will be willing to be vaccinated. In this hypothetical situation, socioeconomic restrictions would be maintained until June 14, 2021. The epidemic peak would occur on day 342 of the epidemic with an infection rate of $1.21 \%$ (slightly lower than in variant $A_{1}$ ). The cumulative death rate would be $3.4 \%$, i.e. about 130,000 people would die $\left(96,000\right.$ fewer than in variant $A_{1}$ and 173,000 fewer than in the baseline scenario). It is also worth mentioning that, in contrast to scenario $A_{1}$, the lockdown abolition combined with an ongoing vaccination process does not actually cause an increase in the proportion of infections (six days after the lockdown easing this proportion falls again). The epidemic would end on day 1,084 after its onset. On the day of its end, the proportion of the convalescent population would be about $22 \%$ and about $40 \%$ of the Polish population would be vaccinated (cf. Figures 6.3 and 6.6, Table 6.1). 


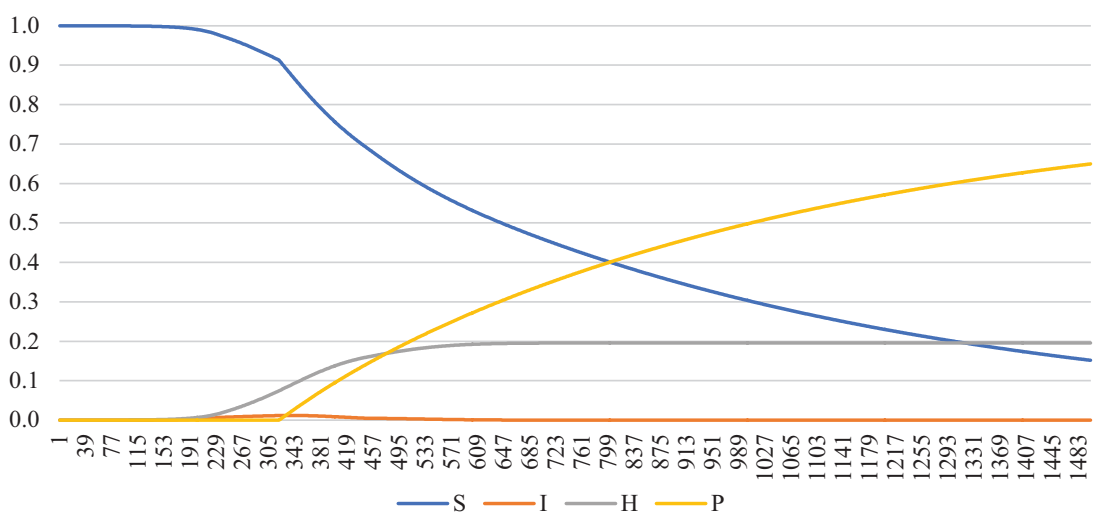

Figure 6.4 Trajectories of proportions $S, I, H$ and $P$ for scenario $\mathrm{A}_{3}(75 \%$ of the population vaccinated). Source: the author's own study.

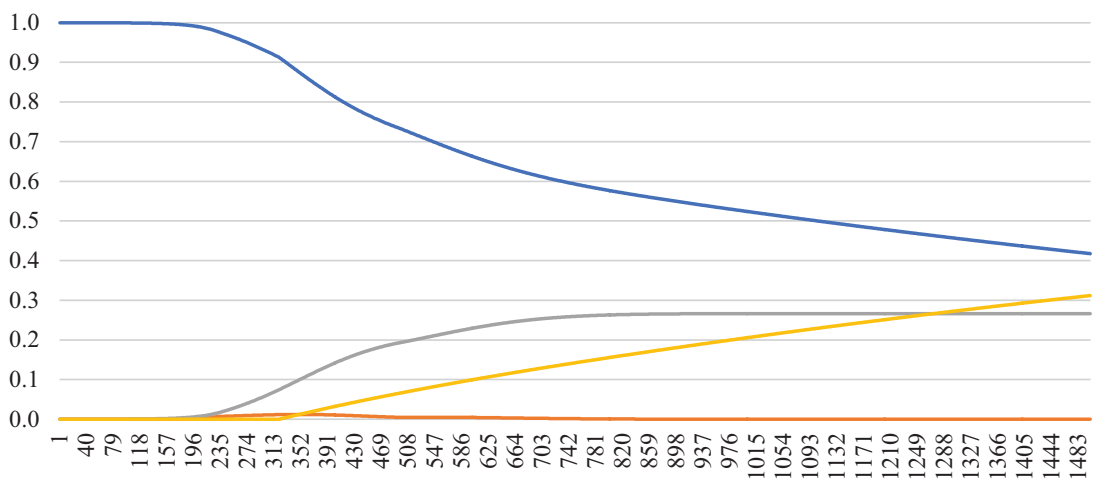
$-\mathrm{S}-\mathrm{I}-\mathrm{H} \longrightarrow \mathrm{P}$

Figure 6.5 Trajectories of proportions $S, I, H$ and $P$ for scenario $\mathrm{A}_{4}(25 \%$ of the population vaccinated). Source: the author's own study.

Variants $\mathrm{A}_{3}$ and $\mathrm{A}_{4}$ are, in turn, optimistic and pessimistic predictions concerning the vaccination of Polish citizens. In the first one, it is assumed that $75 \%$ of the population will be interested in vaccinations, in the second only $25 \%$.

In the optimistic variant, the lockdown would end on 27 May 2021. The peak of the epidemic would occur on day 338 with the maximum proportion of infected individuals at $1.2 \%$ (a similar value to the one in options $\mathrm{A}_{1}$ and $\mathrm{A}_{2}$ ).

The cumulative proportion of deaths would be $3 \%$, i.e. about 115,000 people $\left(15,000\right.$ people fewer than in variant $\left.A_{2}\right)$. The epidemic in Poland would end on day 960 after its beginning, with the proportion 


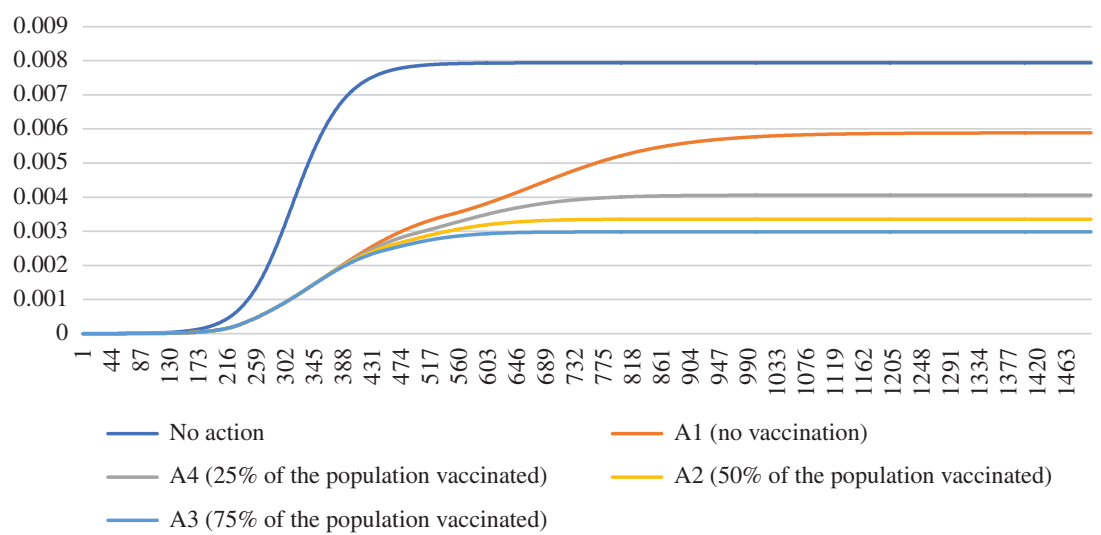

Figure 6.6 Trajectories of death rates for Scenario A. Source: the author's own study.

of vaccinated persons at the level of $48.0 \%$ and convalescents at $19.6 \%$ (Figures 6.4 and 6.6, Table 6.1).

In the pessimistic variant, assuming that the willingness to become vaccinated in Poland will be low, restrictions would be lifted on 12 July 2021. The maximum proportion of the infected persons would be $1.22 \%$ (similar to the value in the previous variants of scenario A) and it would take place on day 349 of the epidemic. After the lockdown abolition, the proportion of infected persons would again start to increase slightly until day 539 of the epidemic, i.e. 24 August 2021, when it would be equal to 5.1\%o (a similar increase after the lockdown easing could be observed under option $A_{1}$ ). The cumulative proportion of deaths would be $4.1 \%$, i.e. 157,000 people would die in Poland (42,000 more than in variant $A_{3}$ ). In Poland, the epidemic would end 1,321 days after its beginning, with the proportion of convalescents equal to $26.7 \%$ (7.1 percentage points more than in variant $\mathrm{A}_{3}$ ) and the proportion of vaccinated persons equal to $27.6 \%$ (20.4 percentage points fewer than in variant $\mathrm{A}_{3}$, cf. Figures 6.5 and 6.6 and Table 6.1).

The next scenario (B) assumes that the restrictions on socioeconomic life are gradually lifted as of 18 January 2021 (the 321st day of the epidemic). This scenario assumes that the rate of the lockdown easing is $5 \%$ per week and thus the restrictions are abolished entirely after four weeks, on day 349 of the epidemic. In variant $B_{1}$ of scenario $B$ (without a vaccine), the maximum number of infected persons will fall on 6 May 2021 (day 429 of the epidemic, see Table 6.2). The proportion of those infected would then be $3.65 \%, 1.29$ percentage points lower than in the baseline scenario (see Figures 6.1 and 6.7 ). In variant $B_{1}$ the proportion of deaths would be $7.5 \%$, which would translate into about 288,000 persons dying as a result of the epidemic. In this variant the number of deaths would decrease by about 


\section{Pawet Dykas et al.}

Table 6.2 Minimum proportion of uninfected persons $\left(\mathrm{S}_{\mathrm{m}}\right)$, maximum proportion of infected persons $\left(I_{M}\right)$, maximum proportion of vaccinated persons $\left(P_{M}\right)$, maximum proportion of convalescents $\left(\mathrm{H}_{\mathrm{M}}\right)$ and the deceased $\left(\mathrm{D}_{\mathrm{M}}\right)$, day of the epidemic with the highest number of infections $(T)$ for scenario $B$ with different variants

\begin{tabular}{lllllll}
\hline variants & $S_{m}$ & $I_{M}$ & $H_{M}$ & $D_{M}$ & $P_{M}$ & $T$ \\
\hline $\mathrm{B}_{1}$ & 0.5023 & 0.0365 & 0.4902 & 0.0075 & 0 & 429 \\
$\mathrm{~B}_{2}$ & 0.2033 & 0.0260 & 0.3617 & 0.0055 & 0.4295 & 411 \\
$\mathrm{~B}_{3}$ & 0.1242 & 0.0229 & 0.3159 & 0.0048 & 0.5551 & 402 \\
$\mathrm{~B}_{4}$ & 0.3239 & 0.0301 & 0.4196 & 0.0064 & 0.2501 & 420 \\
\hline
\end{tabular}

Source: the author's own study.

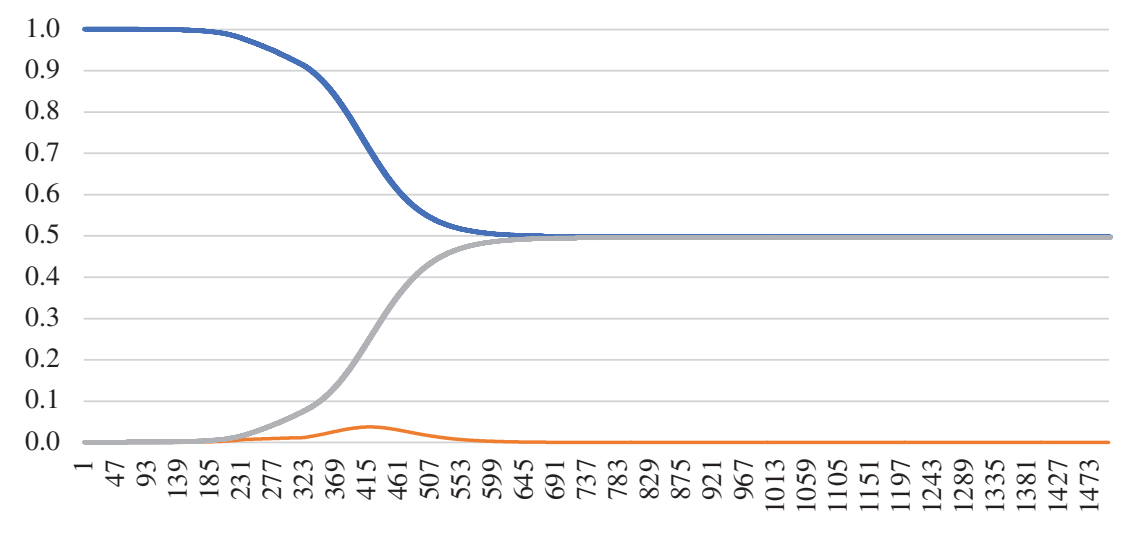

$-\mathrm{S}-\mathrm{I}-\mathrm{H}$

Figure 6.7 Trajectories of proportions $S, I$ and $H$ for scenario $\mathrm{B}_{1}$ (without a vaccine). Source: the author's own study.

15,000 . Moreover, in variant $B_{1}$ the maximum proportion of convalescents would amount to $49.02 \%$ of the Polish population. On the 1,174th day of the epidemic the number of infected persons would fall below one, and on that day the proportion of those who recovered would be about $49.02 \%$ (cf. Figure 6.7).

In subsequent variants, similarly to Scenario A, the vaccination programme is taken into account.

In variant $\mathrm{B}_{2}(50 \%$ of the population vaccinated $)$, it is assumed that the declared proportion of the population that expresses the willingness to receive vaccinations is $50 \%$. In this option, the maximum proportion of infected persons would fall on 18 April 2021, the 411th day of the epidemic, and it would be $2.6 \%$ of the population $\left(28.8 \%\right.$ lower than in option $\mathrm{B}_{1}$ without a vaccine). The number of people who died as a result of the epidemic under this option would decrease by 77,000 compared to option $B_{1}$ 

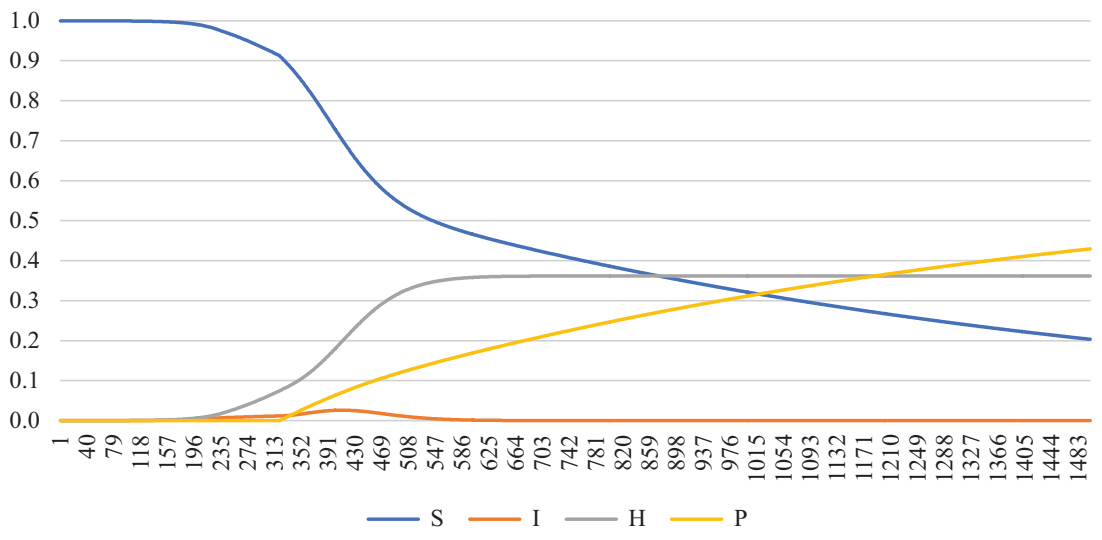

Figure 6.8 Trajectories of proportions $S, I, H$ and $P$ for scenario $\mathrm{B}_{2}(50 \%$ of the population vaccinated). Source: the author's own work.

and would be about 211,000 . With variant $\mathrm{B}_{2}$, the epidemic would end on day 945 , when there would be $29.5 \%$ of vaccinated persons and $36.2 \%$ of convalescents in the Polish population (see Figure 6.8).

Figure 6.9 illustrates the trajectories of proportions $S, I, H$ and $P$ resulting from numerical simulations for variant $B_{3}$, where the proportion of persons declaring the willingness to be vaccinated is $75 \%$ of the population. With this option, the maximum number of infected persons would occur 27 days earlier than with option $B_{1}$ and would be on 9 April 2021 (day 402 of the epidemic, see Table 6.2). The proportion of people infected on this date would be $2.29 \%$, approximately $37.4 \%$ lower than for the no-vaccine option.

The proportion of deaths in variant $\mathrm{B}_{3}$ decreased as compared to both variant $B_{1}$ and variant $B_{2}$ (by $36.0 \%$ and $12.7 \%$ respectively) and was $4.8 \%$. This would translate into approximately 184,000 people dying as a result of the epidemic. Moreover, on 7 August 2022, i.e. on the 887th day, the epidemic would end (counting from the onset) and on that day there would be $38.8 \%$ of vaccinated persons and $31.6 \%$ of convalescents in the Polish population.

The final, fourth variant $\left(\mathrm{B}_{4}\right)$ of scenario $\mathrm{B}$ assumes that only $25 \%$ of the Polish population declare their willingness to be vaccinated (variant $\mathrm{B}_{4}$ ).

The maximum number of infected persons would then be recorded on 27 April 2021, i.e. on day 420 of the epidemic. The maximum proportion of infected persons in this variant would be $3.01 \%$ of the population and it would be $17.5 \%$ lower than in the variant without a vaccine and, respectively, $15.8 \%$ and $31.4 \%$ higher than in variants $\mathrm{B}_{2}$ and $\mathrm{B}_{3}$ (cf. Table 6.2 ).

In the variant $\mathrm{B}_{4}$ the maximum proportion of deaths is $6.4 \%$ of the Polish population, which translates into about 245,000 dead people, and in comparison with the previous variants, it would increase the number of dead 


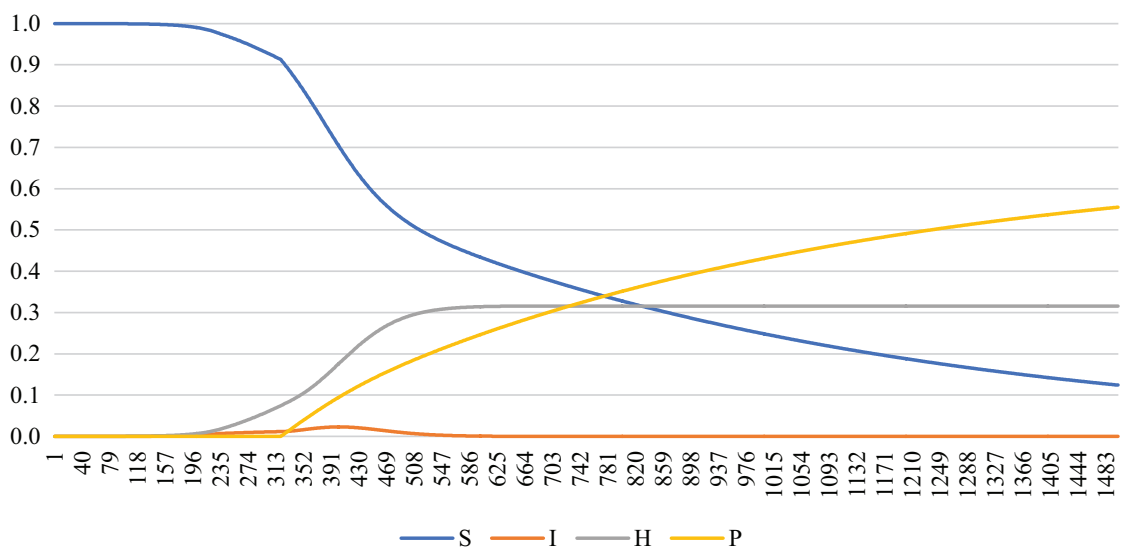

Figure 6.9 Trajectories of proportions $S, I, H$ and $P$ for scenario $\mathrm{B}_{3}(75 \%$ of the population vaccinated). Source: the author's own study.

people by about 34,000 for variant $B_{2}$ and by about 61,000 for variant $B_{3}$ (compare Figure 6.11 and Table 6.2). The epidemic in Poland would end on day 1,026 when there would be $17.2 \%$ vaccinated persons and $41.9 \%$ convalescents in the Polish population (cf. Figure 6.10).

In the third scenario $(\mathrm{C})$, the socioeconomic restrictions associated with the lockdown are to be lifted on 18 January 2021 (day 321 of the epidemic). In scenario $\mathrm{C}_{1}$ (without a vaccine), the maximum number of infected persons would be recorded on 25 April 2021 (418th day of the epidemic).

The proportion of infected persons on that day would be $3.8 \%$ of the population and it would be 1.15 percentage points lower than in the baseline scenario (cf. Table 6.3). The maximum proportion of deaths would translate into over 291,000 people dying as a result of the epidemic, which is approximately 12,000 fewer than compared with the baseline scenario.

In Scenario $C_{1}$, the epidemic would be extinguished after 1,145 days and the proportion of convalescents on that date would be $49.6 \%$ (see Figure 6.12). In scenario $C$ including a vaccination programme with a $50 \%$ vaccination coverage rate, the maximum number of infected persons (day 402 of the epidemic) is observed 16 days earlier as compared with scenario $\mathrm{C}$ without a vaccine (see Table 6.3$)$. In variant $\mathrm{C}_{2}(50 \%$ of the population vaccinated), the maximum proportion of deaths in the population would be $5.8 \%$, which would translate into approximately 222,000 deaths. What follows is that in scenario $\mathrm{C}$ with a vaccination programme and $50 \%$ of the population declaring their willingness to be vaccinated there will be a reduction in deaths due to the epidemic by about 69,000 people. Analyzing the trajectories of proportions $S, I, H$ and $P$ (cf. Figure 6.13) it can be seen that on 16 September 2022, after 927 days, the epidemic will have expired. Then 


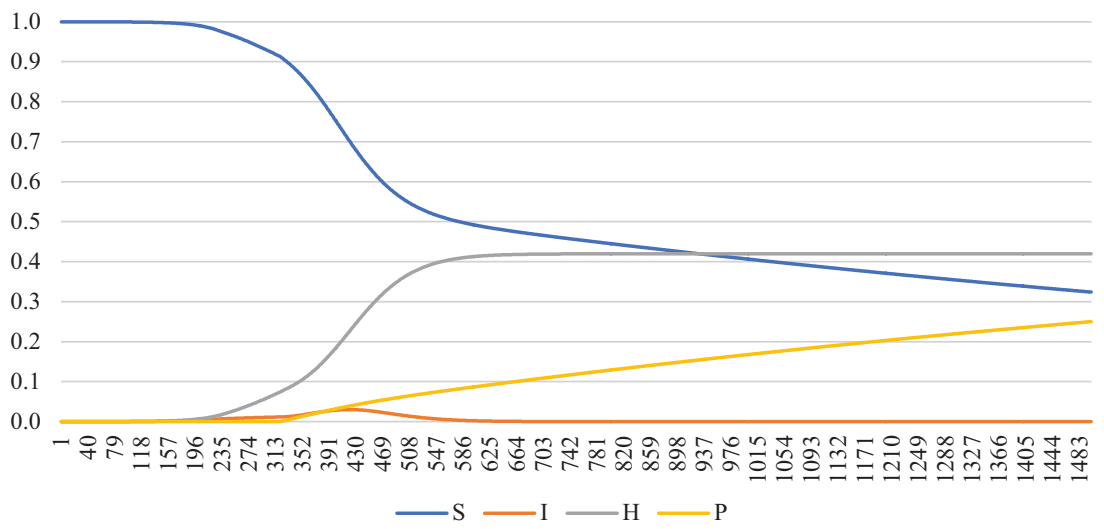

Figure 6.10 Trajectories of proportions $S, I, H$ and $P$ for scenario $\mathrm{B}_{4}(25 \%$ of the population vaccinated). Source: the author's own study.

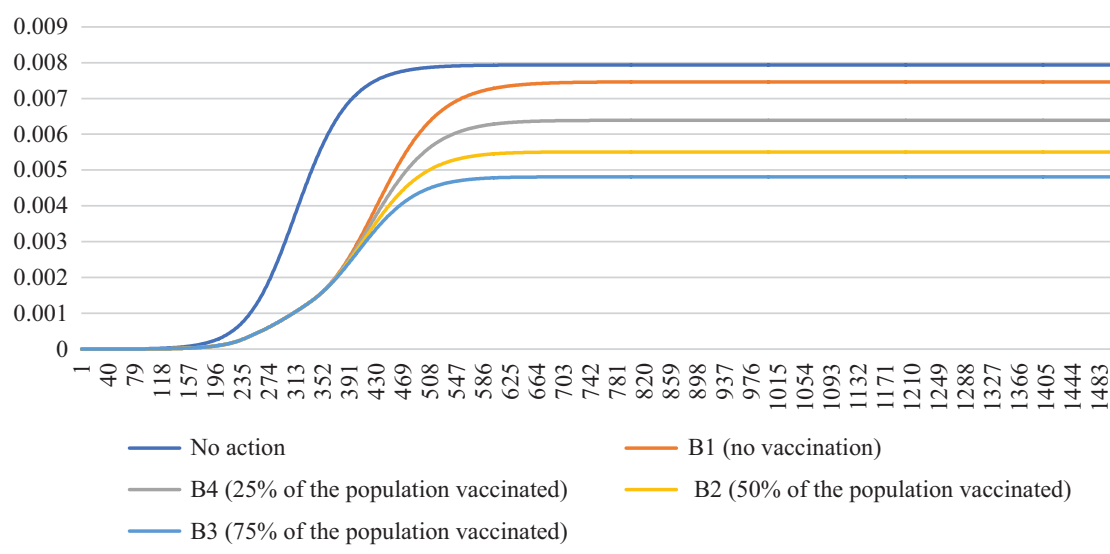

Figure 6.11 Trajectories of death rates for Scenario B. Source: the author's own study.

Table 6.3 Minimum proportion of uninfected persons $\left(\mathrm{S}_{\mathrm{m}}\right)$, maximum proportion of infected persons $\left(I_{M}\right)$, maximum proportion of vaccinated persons $\left(P_{M}\right)$, maximum proportion of convalescents $\left(\mathrm{H}_{\mathrm{M}}\right)$ and the deceased $\left(\mathrm{D}_{\mathrm{M}}\right)$, day of the epidemic with the highest number of infections $(\mathrm{T})$ for scenario $\mathrm{C}$ with different variants

\begin{tabular}{lllllll}
\hline variants & $S_{m}$ & $I_{M}$ & $H_{M}$ & $D_{M}$ & $P_{M}$ & $T$ \\
\hline $\mathrm{C}_{1}$ & 0.4966 & 0.0379 & 0.4958 & 0.0076 & 0 & 418 \\
$\mathrm{C}_{2}$ & 0.1976 & 0.0293 & 0.3787 & 0.0058 & 0.4180 & 402 \\
$\mathrm{C}_{3}$ & 0.1202 & 0.0264 & 0.3357 & 0.0051 & 0.5390 & 394 \\
$\mathrm{C}_{4}$ & 0.3171 & 0.0330 & 0.4318 & 0.0066 & 0.2445 & 410 \\
\hline
\end{tabular}

Source: the author's own study. 


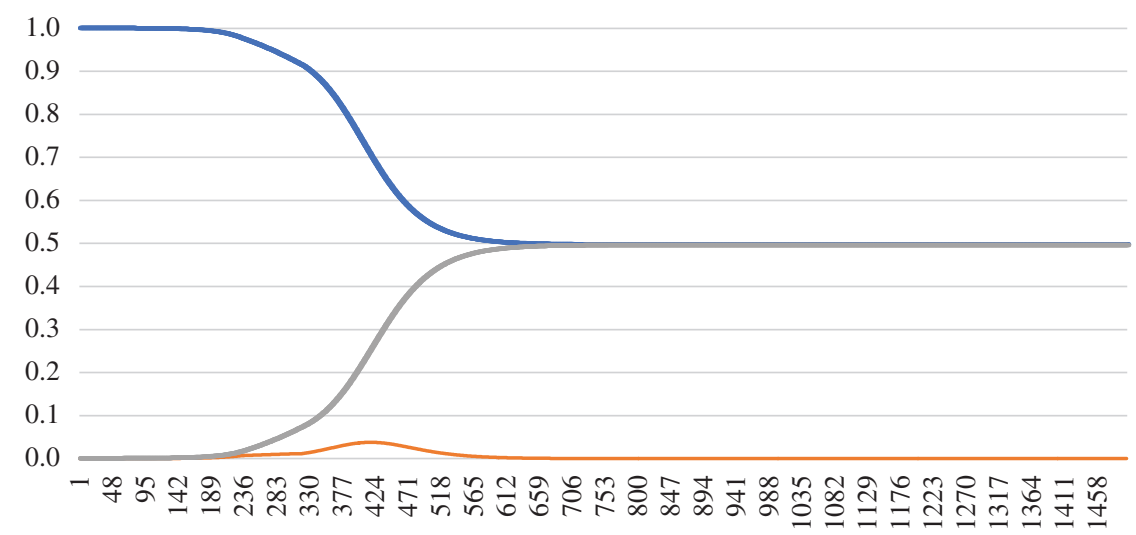

$-\mathrm{S}-\mathrm{I}-\mathrm{H}$

Figure 6.12 Trajectories of proportions $S, I$ and $H$ for scenario $C_{1}$ (without a vaccine). Source: the author's own study.

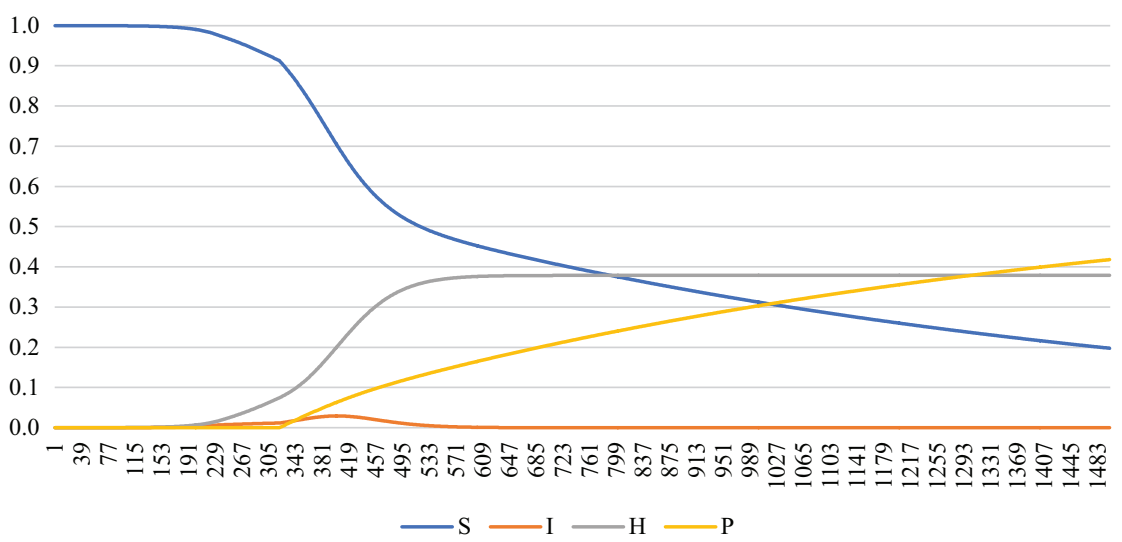

Figure 6.13 Trajectories of proportions $S, I, H$ and $P$ for scenario $C_{2}(50 \%$ of the population vaccinated). Source: the author's own study.

the population will include $28.1 \%$ vaccinated persons and $37.9 \%$ convalescents. Considering variant $\mathrm{C}_{3}(75 \%$ of the population vaccinated) it can be seen that the peak of the epidemic would then fall on 1 April 2021 (day 394 of the epidemic).

The maximum proportion of people infected in this variant of scenario $\mathrm{C}$ would be lower as compared to both variant $\mathrm{C}_{1}$ (reduction by 1.15 percentage points) and variant $\mathrm{C}_{2}$ (reduction by 0.29 percentage points) and equal to $2.6 \%$. The maximum proportion of deaths in variant $\mathrm{C}_{3}$ would be $5.1 \%$, which, taking into account the population of Poland, translates into over 195,000 deaths. After 873 days (July 24, 2022) the epidemic would die out, 

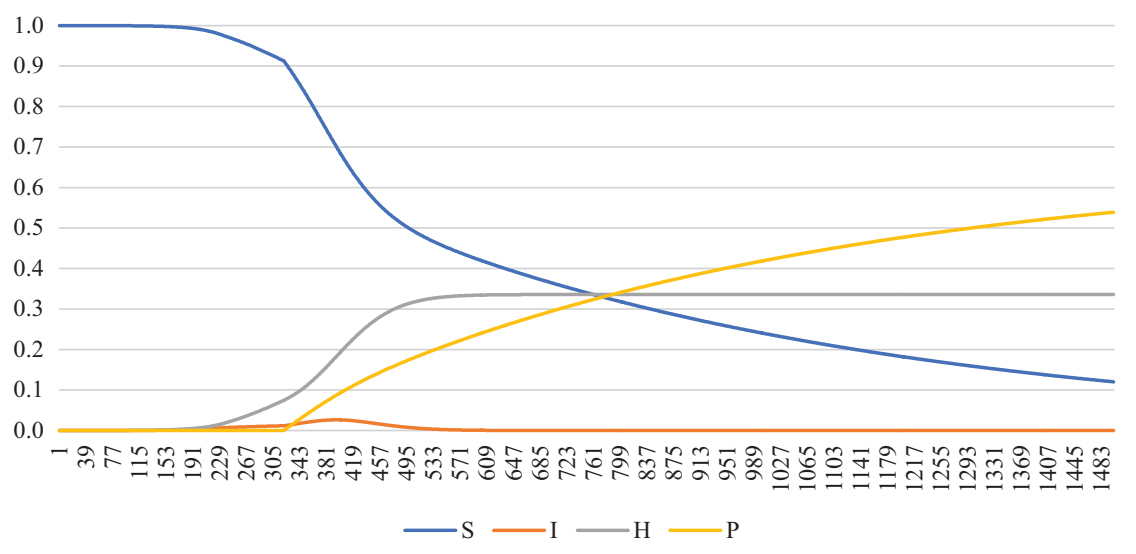

Figure 6.14 Trajectories of proportions $S, I, H$ and $P$ for scenario $C_{3}(75 \%$ of the population vaccinated). Source: the author's own work.

at which date there would be $37.2 \%$ vaccinated persons and $33.6 \%$ convalescents (see Figure 6.14).

In the final variant $\mathrm{C}_{4}$ ( $25 \%$ of the population vaccinated) of this scenario, it is assumed that the proportion of the population declaring a willingness to be vaccinated is $25 \%$. In this scenario, the maximum proportion of infected people would be $3.3 \%$ and it would fall on April 17, 2021 (the 410th day of the epidemic). Under option $C_{4}$, the maximum proportion of deaths would be $6.6 \%$, corresponding to more than 253,000 people dying from the epidemic. As compared with options $\mathrm{C}_{1}-\mathrm{C}_{3}$, the number of the deceased would be higher than under options $C_{2}$ and $C_{3}$ by about 31,000

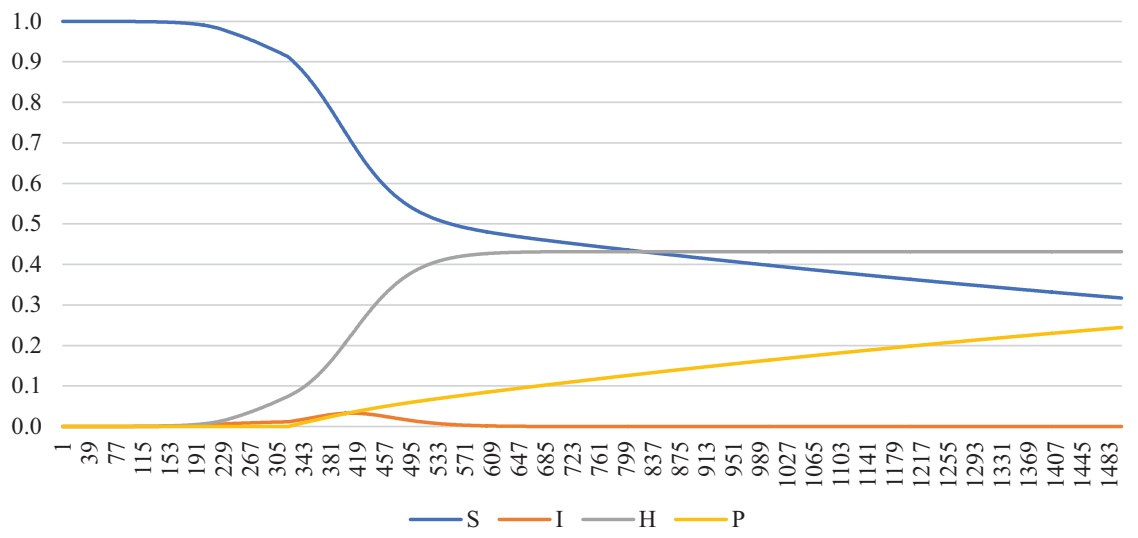

Figure 6.15 Trajectories of proportions $S, I, H$ and $P$ for Scenario $C_{4}(25 \%$ of the population vaccinated). Source: the author's own study. 


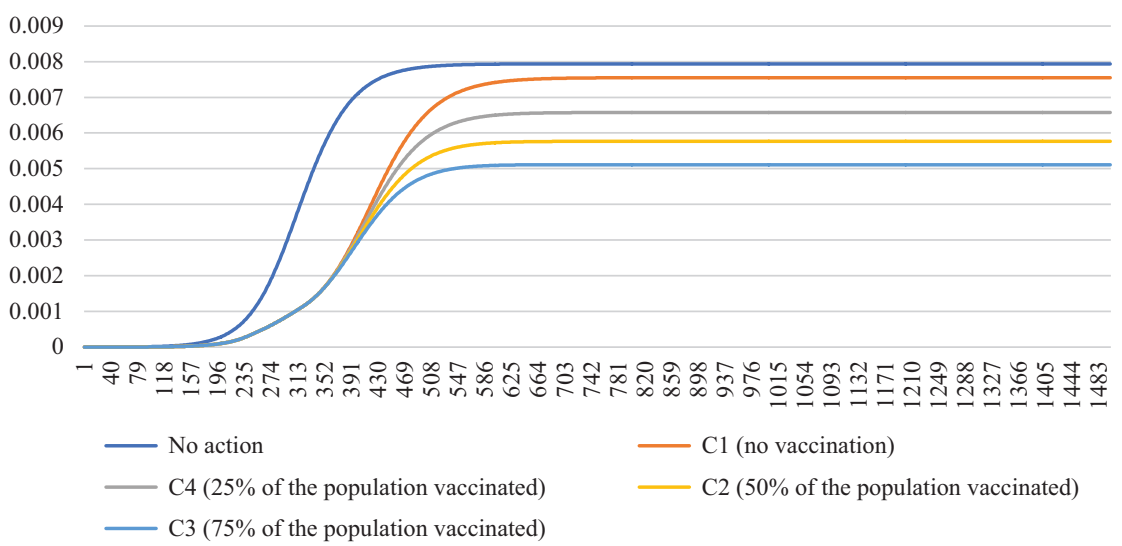

Figure 6.16 Trajectories of death rates for Scenario C. Source: the author's own study.

and 58,000 people, respectively, and lower by 38,000 people when compared with $\mathrm{C}_{1}$ (see Table 6.3 and Figure 6.16). The epidemic following this variant would cease as of day 1,004 (cf. Figure 6.15). Moreover, on that day there would be $16.4 \%$ vaccinated persons and $43.2 \%$ convalescents.

\subsubsection{Results of numerical simulations for Ukraine}

The baseline scenario assumes that the government of Ukraine has not introduced any epidemic-related restrictions in March 2020. This scenario will serve as a baseline for the other scenarios. The peak of the epidemic would occur on day 283 after the outbreak (i.e. around 11 December 2020), and the maximum proportion of infections on that day would be $6.9 \%$. The cumulative death rate would be $8.5 \%$, i.e. about 355,000 people would die. The epidemic would die out after about 2 years (day 774 ) with $43.2 \%$ uninfected persons and $55.9 \%$ convalescents at the end of the epidemic (cf. Figure 6.17).

In scenario A, it is assumed that the lockdown would be lifted when the proportion of infections falls below $50 \%$ of the empirical proportion on day 276 . In the case analyzed, this proportion would be $4.21 \%$. In scenario $\mathrm{A}_{1}$ (without a vaccine), the lockdown would end on 8 October 2021 (day 584 of the epidemic). The maximum proportion of infections is $1.46 \%$ on day 391 of the epidemic, which is 4.4 percentage points lower than in the baseline scenario. When the restrictions are lifted, the proportion of infected individuals would only rise to $5.9 \%$ on day 714 of the epidemic and then fall to 728 people on day 1,500 of the epidemic. In this scenario, the proportion of uninfected persons at the end of the epidemic was equal to $59.9 \%$, while the proportion of convalescents was $40.2 \%$. The cumulative death rate would be $6.1 \%$, i.e. about 256,000 people would die. This is about 


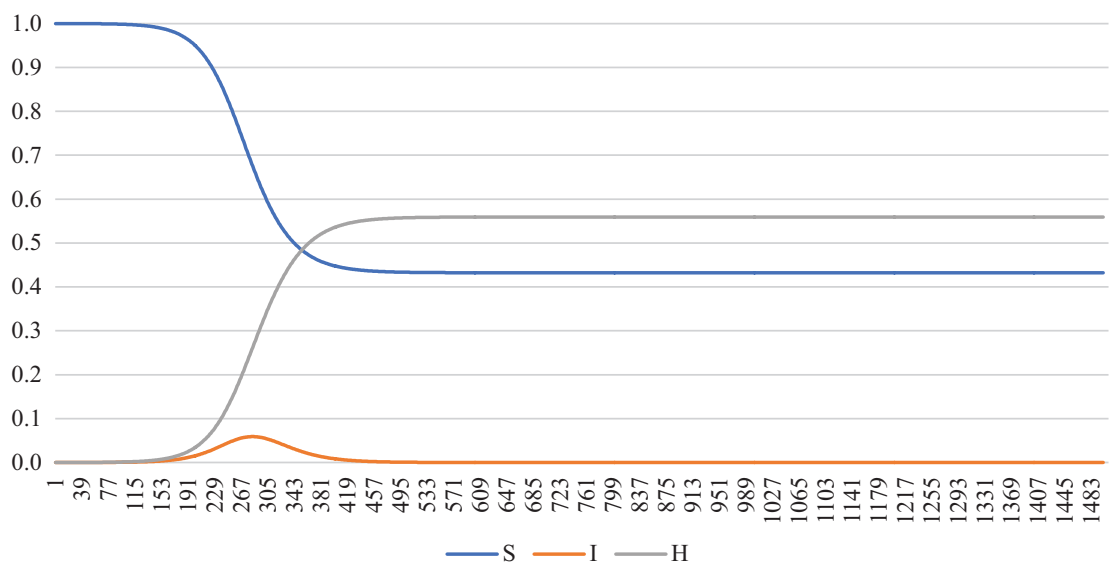

Figure 6.17 Trajectories of proportions $S, I$ and $H$ for the baseline scenario. Source: the author's own study.

99,000 fewer than in the baseline scenario. (See Figures 6.17 and 6.18, Table 6.4).

Scenario A, options $A_{2}$ ( $60 \%$ of the population vaccinated), $A_{3}$ ( $90 \%$ of the population vaccinated) and $\mathrm{A}_{4}$ (30\% of the population vaccinated), in addition to the lockdown abolition when the proportion of infections falls below $50 \%$ of the actual proportion on day 275 , also took into account the spread of the epidemic when the vaccination process began. On 1 February 2021 (day 335 of the epidemic) the first people with immunity after vaccination will appear (thus reducing the proportion of the population at the risk of infection).

According to option $\mathrm{A}_{2}, 60 \%$ of the Ukrainian population will be vaccinated. In this situation, restrictions would be maintained until 11 July 2021 (day 495 of the epidemic).

The highest proportion of infections would be on day 364 of the epidemic and account for $1.36 \%$. The cumulative proportion of deaths would be $3.4 \%$, i.e. approximately 142,000 people would die. This is 112,000 fewer than in option $A_{1}$ and 213,000 fewer than in the baseline scenario. The epidemic would die out around two and a half years (943 days) after its onset. The population would contain $14.9 \%$ uninfected persons, $20.6 \%$ convalescents and $39.4 \%$ vaccinated persons at the end of the epidemic (see Figures 6.19 and 6.22, Table 6.4).

According to option $\mathrm{A}_{3}, 90 \%$ of the Ukrainian population would be vaccinated. In this situation the lockdown would be maintained until 20 June 2021 (the 474th day of the epidemic). The epidemic peak would occur on 24 February (the 358th day of the epidemic) with the maximum rate of infections at $1.35 \%$. 


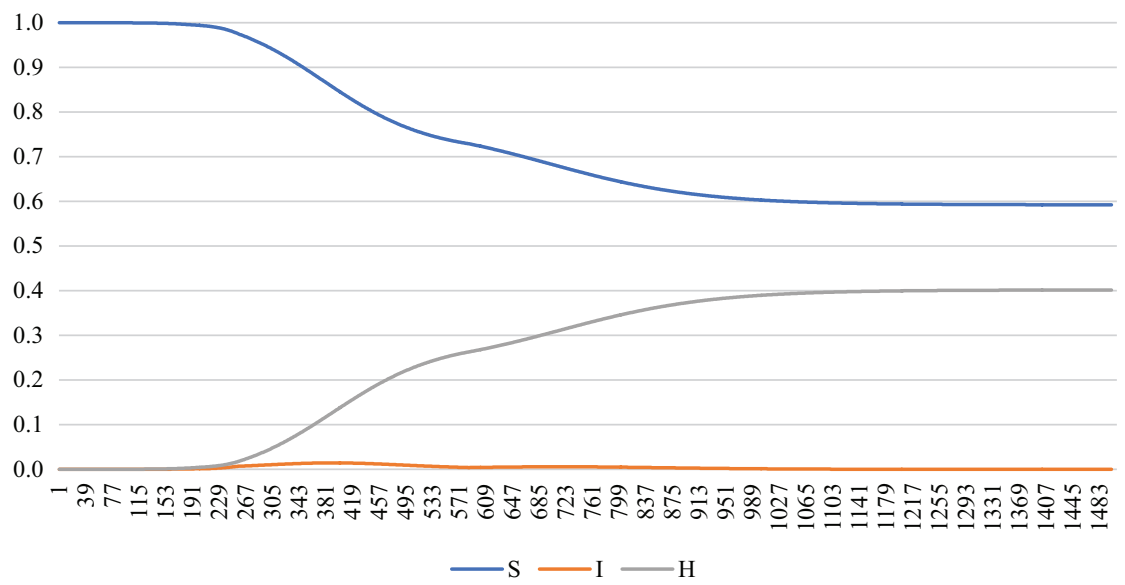

Figure 6.18 Trajectories of proportions $S, I$ and $H$ for scenario $\mathrm{A}_{1}$ (without a vaccine). Source: the author's own study.

Table 6.4 Minimum proportion of uninfected persons $\left(\mathrm{S}_{\mathrm{m}}\right)$, maximum proportion of infected persons $\left(I_{M}\right)$, maximum proportion of vaccinated persons $\left(P_{M}\right)$, maximum proportion of convalescents $\left(\mathrm{H}_{\mathrm{M}}\right)$ and the deceased $\left(\mathrm{D}_{\mathrm{M}}\right)$, day of the epidemic with the highest number of infections $(\mathrm{T})$ for scenario $\mathrm{A}$ with different variants

\begin{tabular}{lllllll}
\hline variants & $S_{m}$ & $I_{M}$ & $H_{M}$ & $D_{M}$ & $P_{M}$ & $T$ \\
\hline $\mathrm{A}_{1}$ & 0.5923 & 0.0146 & 0.4016 & 0.0061 & 0 & 714 \\
$\mathrm{~A}_{2}$ & 0.149425 & 0.013683 & 0.206078 & 0.003138 & 0.641359 & 364 \\
$\mathrm{~A}_{3}$ & 0.065211 & 0.013493 & 0.186179 & 0.002835 & 0.745775 & 358 \\
$\mathrm{~A}_{4}$ & 0.326729 & 0.014001 & 0.245820 & 0.003743 & 0.423707 & 373 \\
\hline
\end{tabular}

Source: the author's own study.

The cumulative death rate would be $2.8 \%$, i.e. about 118,000 people would die. This is almost the same as under option $A_{2}, 138,000$ fewer than under option $A_{1}$ and 237,000 fewer than in the baseline scenario. The epidemic would die out 2 years (827 days) after its onset. There would be $6.5 \%$ uninfected individuals, $18.6 \%$ convalescents and $46.3 \%$ vaccinated persons at the end of the epidemic (cf. Figures 6.20 and 6.22, Table 6.4).

In scenario $\mathrm{A}_{4}$, it was assumed that the willingness to become vaccinated would be low, thus $30 \%$ of the Ukrainian population would be vaccinated. In this situation, restrictions would be maintained until 12 August 2021 (the 527th day of the epidemic). The highest proportion of infected individuals would be on 24 February 2021 (day 373 of the epidemic) representing $1.4 \%$. The cumulative proportion of deaths would be $3.7 \%$, or about 156,000 people would die. This is 200,000 fewer people than in the baseline 


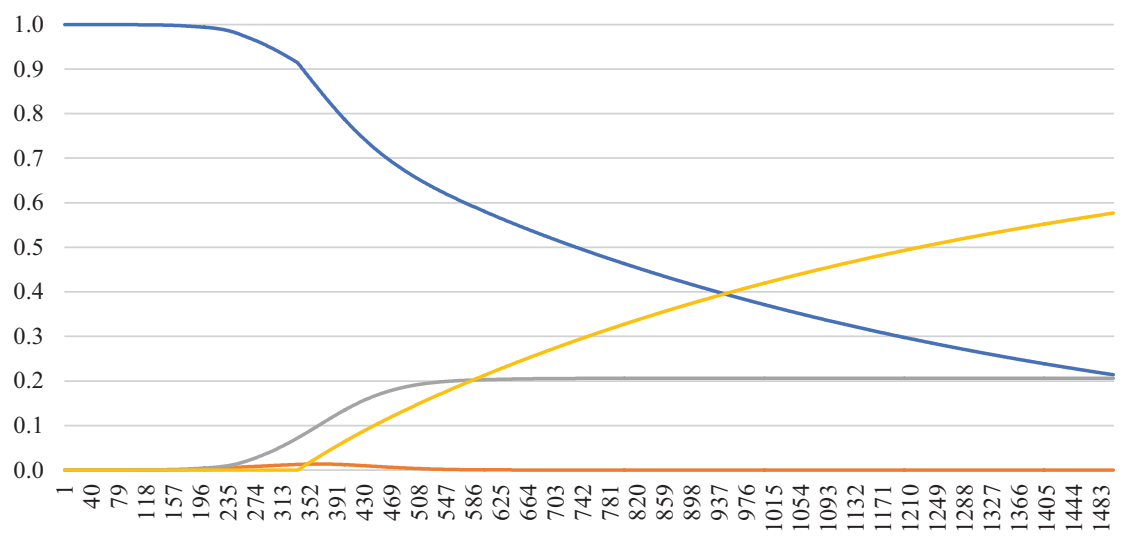

$\longrightarrow \mathrm{S}-\mathrm{I} \longrightarrow \mathrm{H} \longrightarrow \mathrm{P}$

Figure 6.19 Trajectories of proportions $S, I, H$ and $P$ for scenario $\mathrm{A}_{2}(60 \%$ of the population vaccinated). Source: the author's own study.

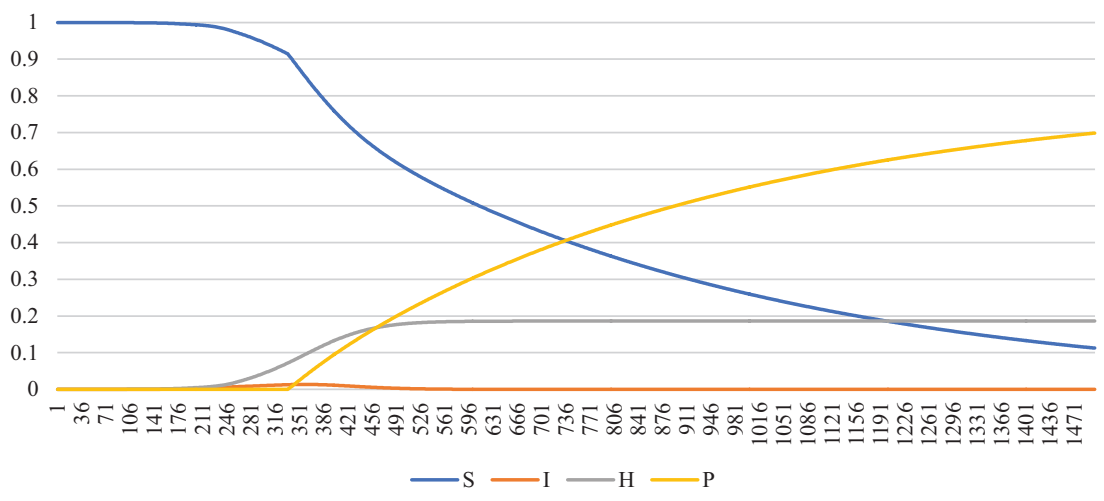

Figure 6.20 Trajectories of proportions $S, I, H$ and $P$ for scenario $\mathrm{A}_{3}$ (90\% of the population vaccinated). Source: the author's own study.

scenario. In contrast, this option predicts the highest number of deaths of all the variants that include a vaccine. The epidemic would die out three years (1,190 days) after its onset. There would be $32.7 \%$ uninfected individuals, $24.6 \%$ convalescents and $28.8 \%$ vaccinated persons at the end of the epidemic (cf. Figures 6.21 and 6.22, Table 6.4).

In scenario $\mathrm{B}$, it is assumed that restrictions on socioeconomic life are to be gradually lifted starting from 30 January 2021 (the 333rd day of the epidemic). It is assumed that the rate of lockdown easing is $5 \%$ per week. In this scenario, restrictions will be entirely removed after four weeks, on day 362 of the epidemic. In variant $B_{1}$ (without a vaccine) the peak of the 


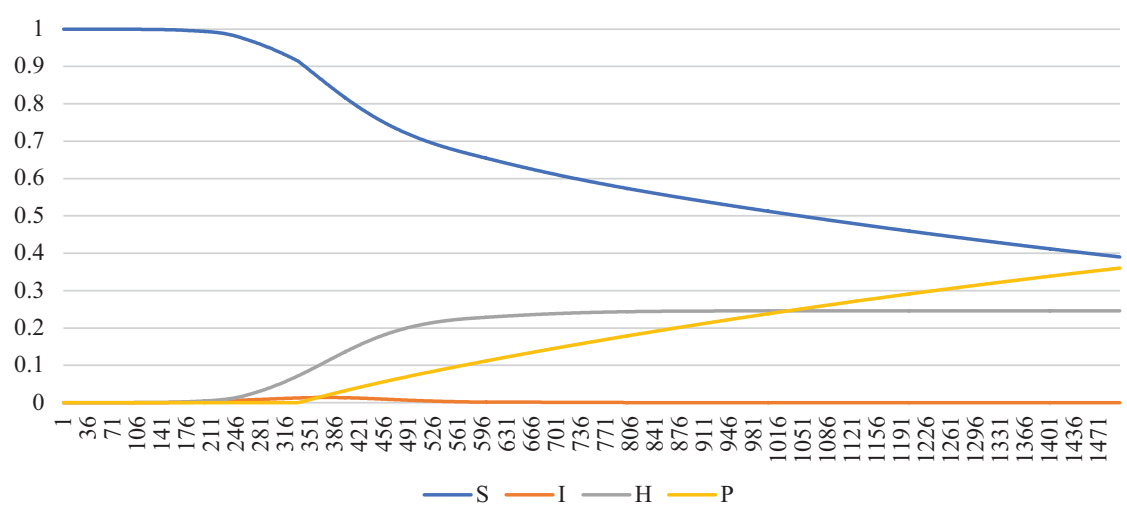

Figure 6.21 Trajectories of proportions $S, I, H$ and $P$ for scenario $\mathrm{A}_{4}$ (30\% of the population vaccinated). Source: the author's own study.

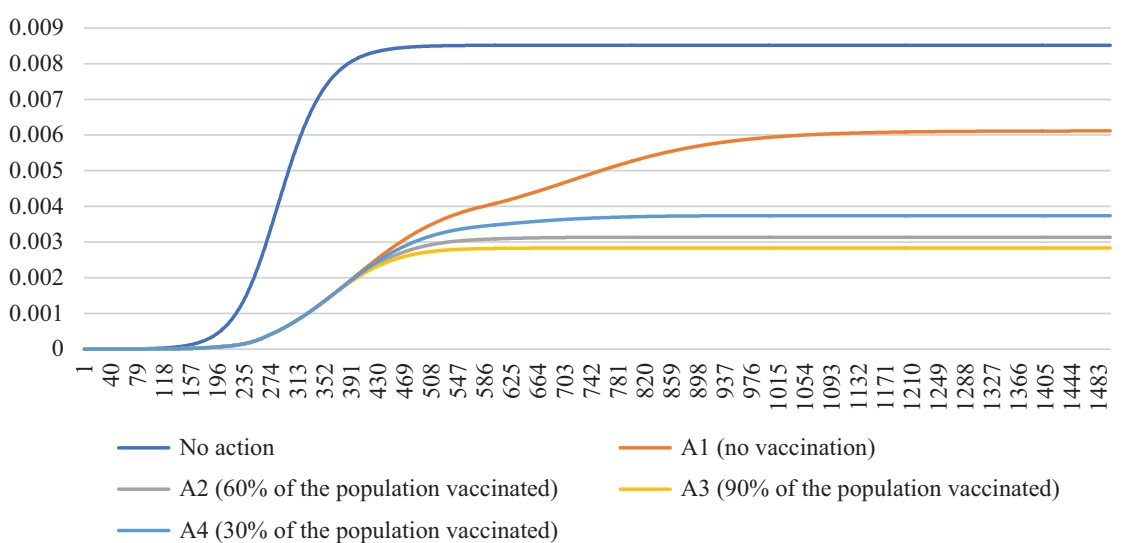

Figure 6.22 Trajectories of death rates for Scenario A. Source: the author's own study.

epidemic would be on 13 May (the 436th day of the epidemic) with the maximum proportion of infections at $4.37 \%$, which is almost 2 million people. The cumulative death rate would be $8 \%$, i.e. about 334,000 people would die. This is 21,000 fewer than in the baseline scenario.

The epidemic would die out nearly three years (983 days) after its onset. There would be $46.2 \%$ uninfected individuals and $52.9 \%$ convalescents after the end of the epidemic (cf. Figure 6.23 and 6.27, Table 6.5).

The following variants of scenario $B$ take into account the vaccination of the population. In variant $B_{2}$ it was assumed that $60 \%$ of the population would be vaccinated. In this situation the highest proportion of infected persons would fall on 27 April 2021 (the 364th day of the epidemic) at 3.12\%. As a result of 


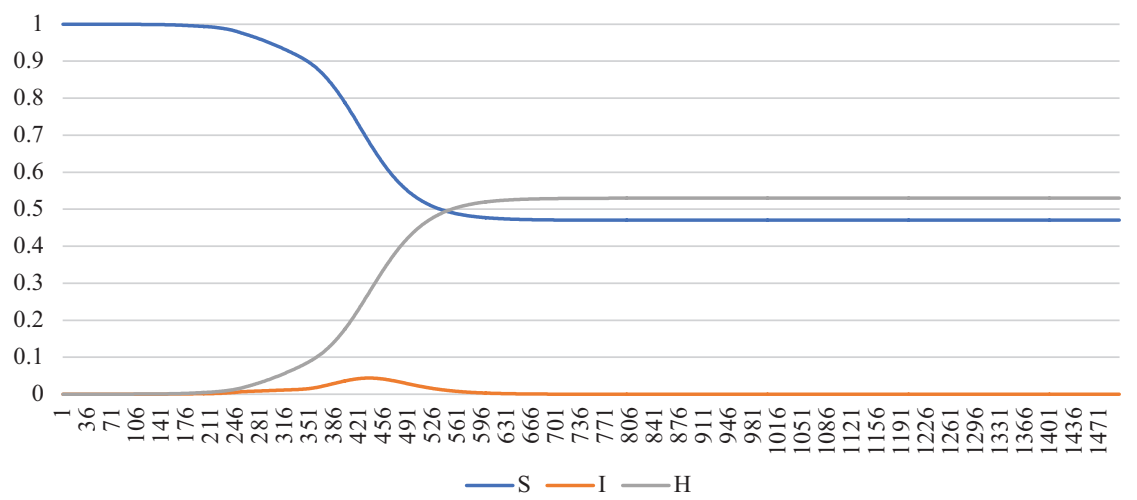

Figure 6.23 Trajectories of proportions $S, I$ and $H$ for scenario $\mathrm{B}_{1}$ (without a vaccine). Source: the author's own study.

Table 6.5 Minimum proportion of uninfected persons $\left(\mathrm{S}_{\mathrm{m}}\right)$, maximum proportion of infected persons $\left(I_{M}\right)$, maximum proportion of vaccinated persons $\left(P_{M}\right)$, maximum proportion of convalescents $\left(\mathrm{H}_{\mathrm{M}}\right)$ and the deceased $\left(\mathrm{D}_{\mathrm{M}}\right)$, day of the epidemic with the highest number of infections $(\mathrm{T})$ for scenario $\mathrm{B}$ with different variants

\begin{tabular}{lllllll}
\hline variants & $S_{m}$ & $I_{M}$ & $H_{M}$ & $D_{M}$ & $P_{M}$ & $T$ \\
\hline $\mathrm{B}_{1}$ & 0.462102 & 0.043753 & 0.529830 & 0.008068 & 0 & 436 \\
$\mathrm{~B}_{2}$ & 0.109040 & 0.031281 & 0.386877 & 0.005892 & 0.498192 & 420 \\
$\mathrm{~B}_{3}$ & 0.050093 & 0.027247 & 0.334960 & 0.005101 & 0.609845 & 412 \\
$\mathrm{~B}_{4}$ & 0.228571 & 0.036675 & 0.451814 & 0.006880 & 0.312734 & 428 \\
\hline
\end{tabular}

Source: the author's own study.

the epidemic, 246,000 people would die. Thus, the cumulative proportion of deaths would be $5.9 \%$. This is 87,000 fewer than in variant $B_{1}$ and 109,000 fewer than in the baseline scenario. The epidemic would die out after two years ( 839 days). There would be $10.9 \%$ uninfected individuals and $38.7 \%$ convalescents after the end of the epidemic (cf. Figure 6.24 and 6.27, Table 6.5).

The following variants of scenario $B$ take into account the vaccination of the population. In variant $B_{2}$ it was assumed that $60 \%$ of the population would be vaccinated. In this situation the highest proportion of infected persons would fall on 27 April 2021 (the 364th day of the epidemic) at $3.12 \%$. As a result of the epidemic, 246,000 people would die. Thus, the cumulative proportion of deaths would be $5.9 \%$. This is 87,000 fewer than in variant $\mathrm{B}_{1}$ and 109,000 fewer than in the baseline scenario. The epidemic would die out after two years ( 839 days). There would be $10.9 \%$ uninfected individuals and $38.7 \%$ convalescents after the end of the epidemic (cf. Figure 6.24 and 6.27, Table 6.5). 


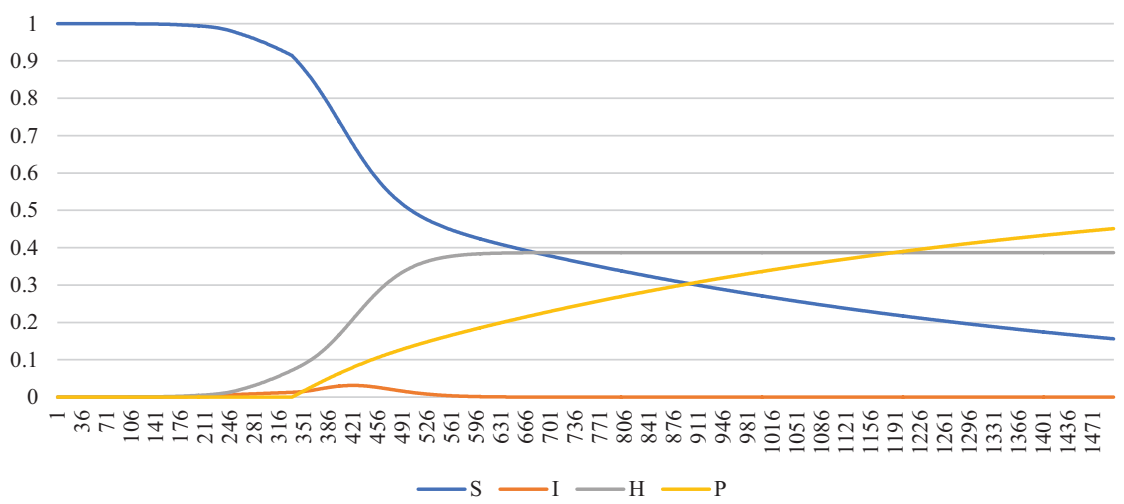

Figure 6.24 Trajectories of proportions $S, I, H$ and $P$ for scenario $\mathrm{B}_{2}(60 \%$ of the population vaccinated). Source: the author's own study.

Variant $\mathrm{B}_{3}$ assumed the most optimistic scenario in which $90 \%$ of the Ukrainian population would be vaccinated. The highest proportion of infections would fall on 19 May 2021 (day 412 of the epidemic) at $2.72 \%$. The cumulative death rate would be 5.1\%o. Approximately 213,000 people would die, which is $3.4 \%$ fewer than in the baseline scenario, $2.9 \%$ o fewer than in option $\mathrm{B}_{1}$ and $0.8 \%$ fewer than in option $\mathrm{B}_{2}$. The epidemic would die out after two years ( 795 days). There would be $5 \%$ uninfected individuals, $33.4 \%$ convalescents and $37.8 \%$ vaccinated persons at the end of the epidemic (cf. Figures 6.25 and 6.27, Table 6.5).

On the other hand, variant $\mathrm{B}_{4}$ is the most pessimistic scenario in which $30 \%$ of the Ukrainian population is vaccinated. In this variant the peak of the epidemic would fall on 5 May (the 428th day of the epidemic) with the maximum proportion of infections at $3.66 \%$, i.e. 1.5 million persons. The cumulative proportion of deaths would be $6.88 \%$.

As a result, about 288,000 people would die. This is 75,000 more people than in option $B_{3}, 42,000$ more than in option $B_{2}, 49,000$ fewer than in the no-vaccine option and 67,000 fewer than in the baseline scenario. The epidemic would die out after two years ( 895 days). There would be $22.8 \%$ uninfected people, $46.4 \%$ convalescents and $16.1 \%$ vaccinated people at the end of the epidemic (see Figures 6.26 and 6.27, Table 6.5).

In the final scenario $\mathrm{C}$, it is assumed that the lockdown restrictions are to be lifted on 30 January 2021 (the 333rd day of the epidemic). In scenario $\mathrm{C}_{1}$ (without a vaccine), the epidemic peak would fall on 1 May (day 424 of the epidemic) with the maximum proportion of infections at $4.67 \%$. The cumulative death rate would be $8.16 \%$, i.e. about 341,000 people would die. This is 14,000 fewer than in the baseline scenario. The epidemic would die out after almost three years (958 days). There would be $45.6 \%$ 


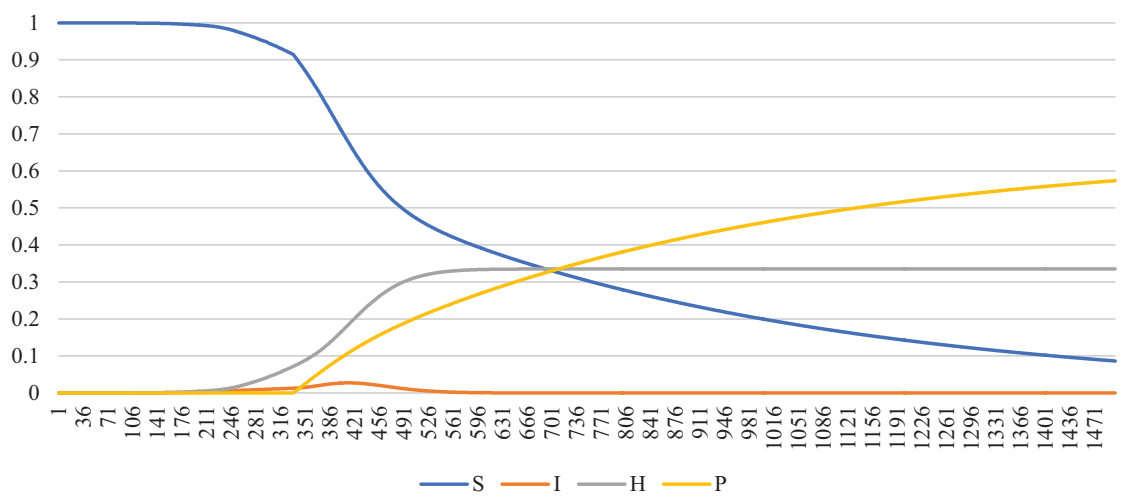

Figure 6.25 Trajectories of proportions $S, I, H$ and $P$ for scenario $\mathrm{B}_{3}(90 \%$ of the population vaccinated). Source: the author's own study.

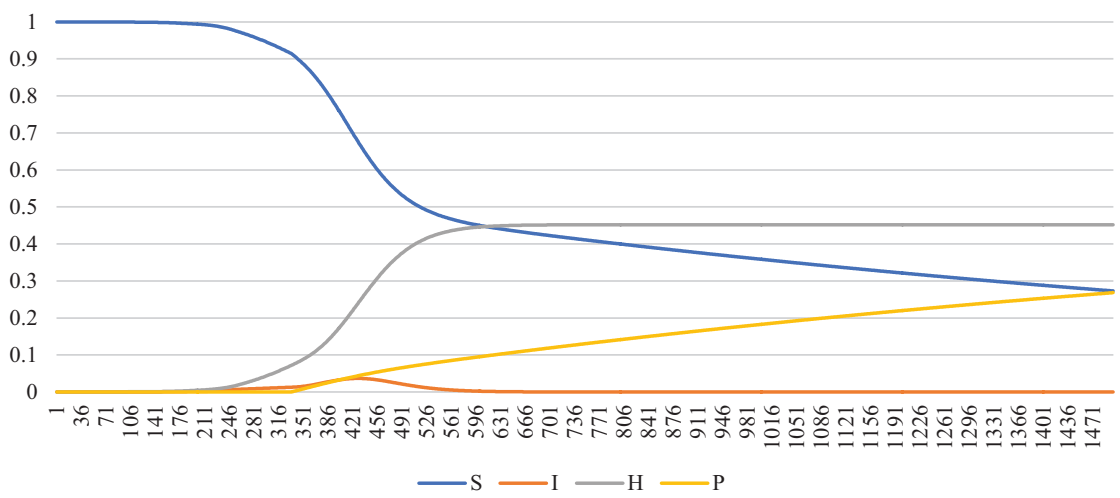

Figure 6.26 Trajectories of proportions $S, I, H$ and $P$ for scenario $\mathrm{B}_{4}(30 \%$ of the population vaccinated). Source: the author's own study.

uninfected individuals and $53.6 \%$ convalescents at the end of the epidemic (see Figures 6.28 and 6.32, Table 6.6).

In the following variants of scenario $\mathrm{C}$, the vaccination programme was taken into account. In variant $\mathrm{C}_{2}$, it was assumed that $60 \%$ of the population would be vaccinated. On the basis of Figure 6.29 it can be deduced that the peak of the epidemic in this variant would fall on 18 April 2021 (day 411 of the epidemic) with the rate of infection at $3.56 \%$. In this variant, 260,000 people would die. Thus, the cumulative proportion of deaths would be $6.2 \%$. This is 81,000 fewer than in option $\mathrm{C}_{1}$ and 95,000 fewer than in the baseline scenario. The epidemic would die out after 2 years ( 821 days). There would be $31.8 \%$ uninfected individuals, $40.7 \%$ convalescents 


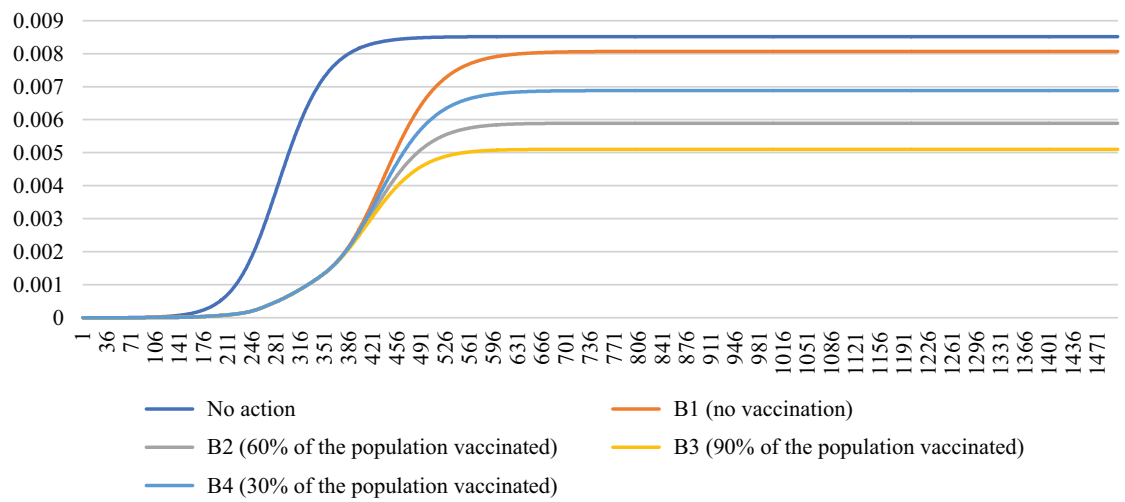

Figure 6.27 Trajectories of death rates for Scenario B. Source: the author's own study.

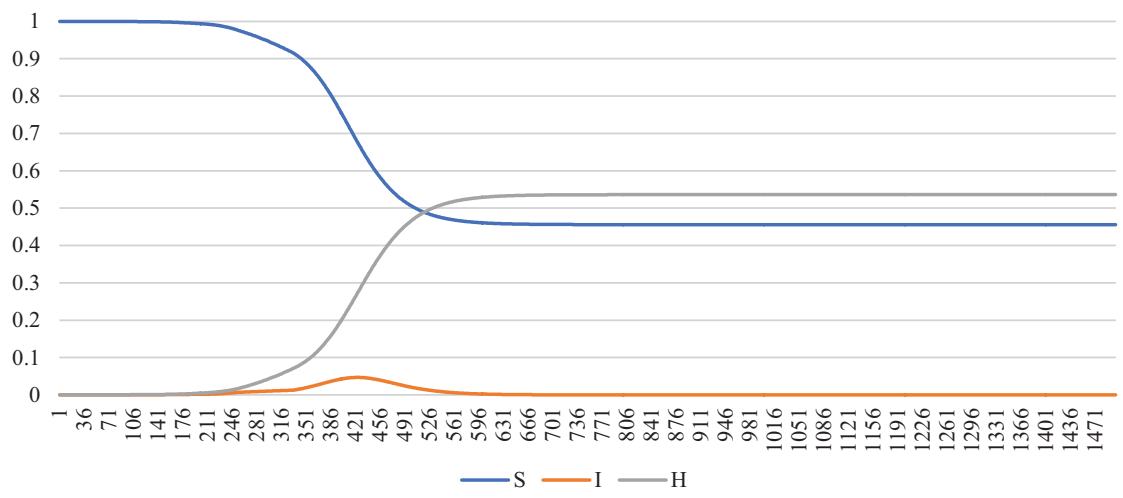

Figure 6.28 Trajectories of proportions $S, I$ and $H$ for scenario $\mathrm{C}_{1}$ (without a vaccine). Source: the author's own study.

Table 6.6 Minimum proportion of uninfected persons $\left(\mathrm{S}_{\mathrm{m}}\right)$, maximum proportion of infected persons $\left(\mathrm{I}_{\mathrm{M}}\right)$, maximum proportion of vaccinated persons $\left(\mathrm{P}_{\mathrm{M}}\right)$, maximum proportion of convalescents $\left(\mathrm{H}_{\mathrm{M}}\right)$ and the deceased $\left(\mathrm{D}_{\mathrm{M}}\right)$, day of the epidemic with the highest number of infections $(\mathrm{T})$ for scenario $\mathrm{B}$ with different variants

\begin{tabular}{lllllll}
\hline variants & $S_{m}$ & $I_{M}$ & $H_{M}$ & $D_{M}$ & $P_{M}$ & $T$ \\
\hline $\mathrm{C}_{1}$ & 0.455823 & 0.046713 & 0.536014 & 0.008163 & 0 & 424 \\
$\mathrm{C}_{2}$ & 0.105171 & 0.035679 & 0.407456 & 0.006205 & 0.481168 & 411 \\
$\mathrm{C}_{3}$ & 0.048006 & 0.031926 & 0.359403 & 0.005473 & 0.587119 & 404 \\
$\mathrm{C}_{4}$ & 0.222649 & 0.040525 & 0.466172 & 0.007099 & 0.304080 & 417 \\
\hline
\end{tabular}

Source: the author's own study. 


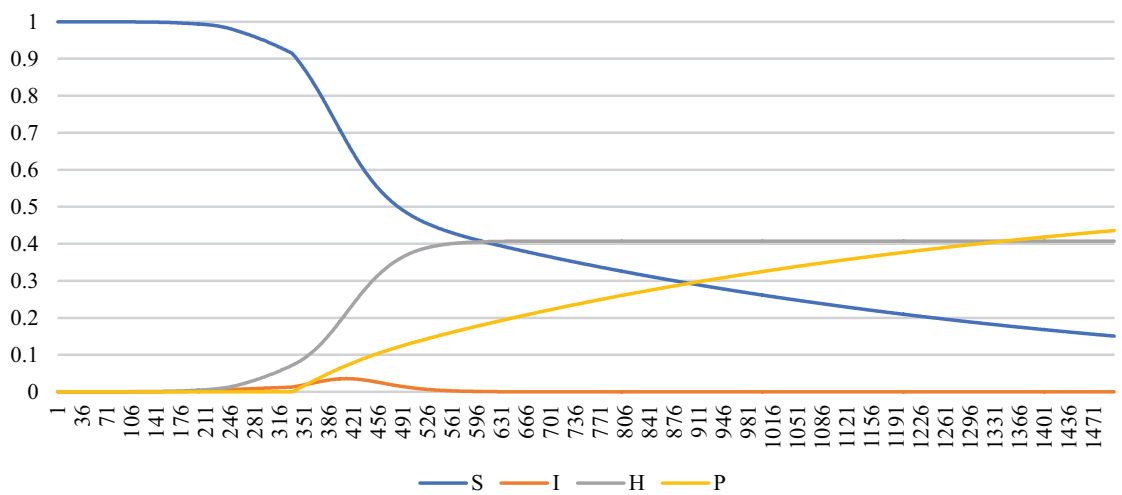

Figure 6.29 Trajectories of proportions $S, I, H$ and $P$ for scenario $C_{2}(60 \%$ of the population vaccinated). Source: the author's own study.

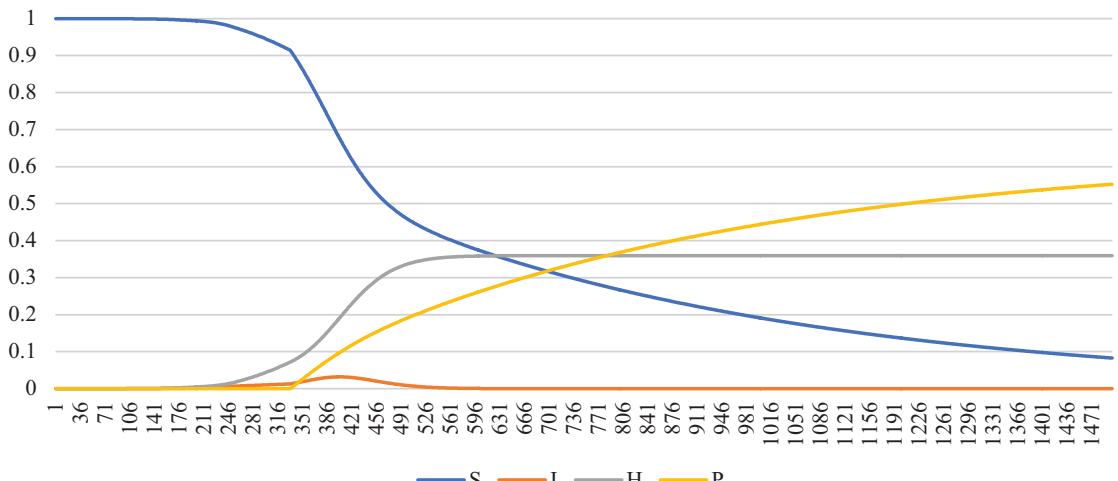

Figure 6.30 Trajectories of proportions $S, I, H$ and $P$ for scenario $C_{3}(90 \%$ of the population vaccinated). Source: the author's own study.

and $48.1 \%$ vaccinated persons at the end of the epidemic (cf. Figure 6.29 and 6.32, Table 6.6).

In scenario $\mathrm{C}_{3}$, with $90 \%$ of the Ukrainian population vaccinated, the highest proportion of infections would fall on 11 April 2021 (day 404 of the epidemic) at $3.19 \%$. The cumulative death rate would be $5.47 \%$. Approximately 229,000 people would die. This is 126,000 fewer people than in the baseline scenario, 112,000 fewer people than in option $C_{1}$ and 31,000 fewer people than in option $\mathrm{C}_{2}$. The epidemic would die out after two years (782 days). There would be $27.6 \%$ uninfected individuals, $35.9 \%$ convalescents and $58.7 \%$ vaccinated persons at the end of the epidemic (see Figures 6.30 and 6.32, Table 6.6).

In the final variant $\mathrm{C}_{4}$ of this scenario, $30 \%$ of the population is assumed to be vaccinated. In this, the most pessimistic variant, the peak of the 


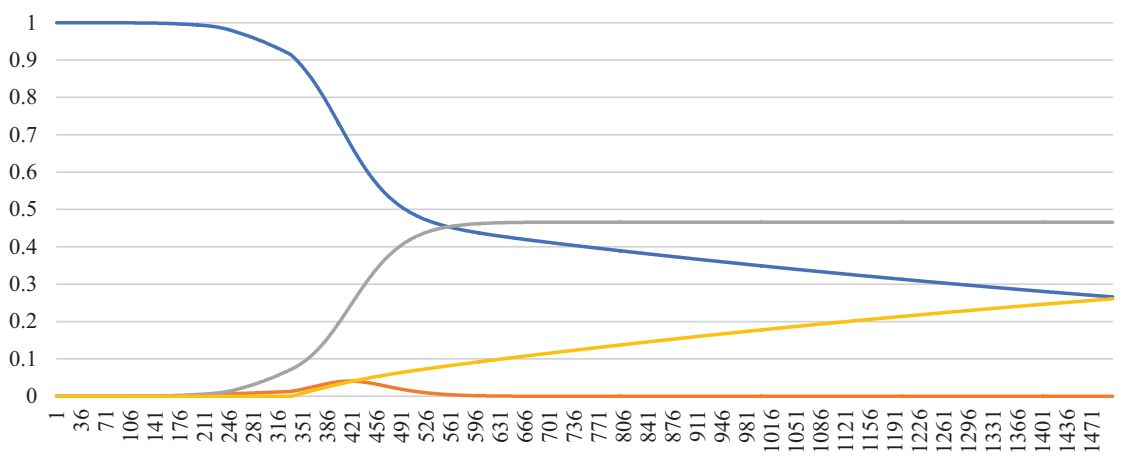

$-\mathrm{S}-\mathrm{I}-\mathrm{H}-\mathrm{P}$

Figure 6.31 Trajectories of proportions $S, I, H$ and $P$ for scenario $\mathrm{C}_{4}(30 \%$ of the population vaccinated). Source: the author's own study.

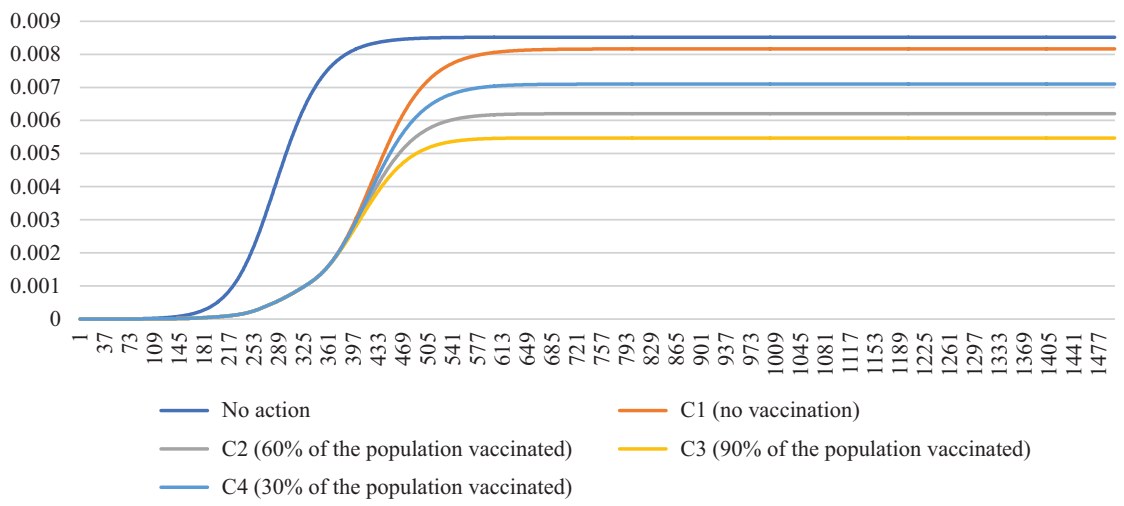

Figure 6.32 Trajectories of death rates for Scenario C. Source: the author's own study.

epidemic would fall on 24 April (day 417 of the epidemic). The maximum proportion of infections on that day would be $4.05 \%$. The cumulative death rate would be $7.1 \%$, i.e. about 297,000 people would die. This is 58000 fewer than in the baseline scenario. The epidemic would die out after 2 years (874 days). There would be $37.4 \%$ uninfected individuals, $46.7 \%$ convalescents and $30.4 \%$ vaccinated persons at the end of the epidemic (see Figures 6.31 and 6.32, Table 6.5).

\subsection{Conclusions}

This chapter analyzes three scenarios of the spread of the epidemic in two selected countries, Poland and Ukraine, depending on the actions taken by 
the government as regards the time and manner of the easing of socioeconomic restrictions. According to scenario A, the lockdown would be lifted when the proportion of infections fell below $50 \%$ of the actual proportion on day 275 of the epidemic. According to scenario B, restrictions would be lifted gradually over one month, beginning on 18 January 2021 in Poland and 30 January 2021 in Ukraine. According to the final scenario C, the lockdown restrictions would be lifted on a single date (18 January 2021 for Poland and 30 January 2021 for Ukraine). Additionally, each of the scenarios includes four variants, one without vaccination and three with the respective vaccination of $50 \%(60 \%), 75 \%(90 \%)$ and $25 \%(30 \%)$ of the Polish (Ukrainian) population.

An important parameter in the assessment of the course of the epidemic is the proportion of deaths. The best results for Poland are achieved with Scenario A in its variants with vaccination. Assuming that $75 \%, 50 \%$ and $25 \%$ of the population will express their willingness to be vaccinated, the proportion of deaths will be as follows: $3 \%$ o (115,000 people), $3.4 \%$ (130,000 people) and 4.1\%o (157,000 people), respectively. For these variants the lockdown would have to be maintained until May 27, June 14 and July 12, 2021, respectively. The highest proportion of deaths can be observed for scenarios $\mathrm{C}$ and $\mathrm{B}$ without vaccination; they are respectively $7.6 \%$ (291,000 people) and 7.5\%o (288,000 people), differing relatively little from the base scenario as regards the free spread of the epidemic $(7.9 \%$, 303,000 people).

Regardless of the variant adopted in Ukraine, the cumulative proportion of deaths would not exceed $8.16 \%$, which represents about 341,000 people. Therefore, the most pessimistic variant would be $\mathrm{C}_{1}$ (lockdown restrictions are lifted on 30 January 2021, there is no vaccination). In the scenario without socioeconomic restrictions, the proportion would be $8.5 \%$ o $(355,000$ people). The most optimistic variant of all discussed is the one where the lockdown would be lifted when the proportion of infections falls below $50 \%$ of the empirical proportion on day 275 and $90 \%$ of the $\mathrm{A}_{3}$ population is vaccinated. In this situation about 118,000 people would die $(2.8 \%$ o).

Another important parameter is the proportion of the population infected at the peak of the epidemic. This parameter indirectly affects the burden on the country's health care system - the more infected people there are, the more people are likely to require hospitalization. Also in this aspect the best results would be achieved by implementing scenario A. In different variants of this scenario, the value of this parameter for Poland oscillates between $1.20-1.24 \%$ (460-476 thousand people), and the pandemic peak would occur relatively early, i.e. on days 338-362 of the epidemic. In contrast, in scenarios $\mathrm{C}$ and $\mathrm{B}$ without vaccination and with the vaccination of $25 \%$ of the population, the proportion is between $3.01-3.79 \%(1,154,000-$ $1,454,000$ people) and the peak would occur on days $410-429$ of the epidemic. With the free spread of the epidemic at the peak, i.e. day 311, the number of active cases would be $4.94 \%$ (approximately 1,895,000 people). 


\section{Pawet Dykas et al.}

In each scenario, the peak of the epidemic in Ukraine would fall the soonest in variant 3 ( $90 \%$ of the population would be vaccinated). The most positive of these variants would be scenario A (socioeconomic restrictions are removed when the proportion of infections falls below $50 \%$ of the empirical proportion on day 275). In this case, the peak of the epidemic would occur on 24 February (day 358 of the epidemic). In addition, this variant has the lowest maximum proportion of infections at $1.35 \%$. On the other hand, the highest maximum proportion of infections would be $4.67 \%$ in variant $C_{1}$ (the lockdown restrictions would be lifted on 30 January 2021). The peak of the epidemic would fall on 1 May (day 424 of the epidemic). The peak of the epidemic would occur the latest on 13 May 2021 (the 436th day of the epidemic) with the maximum proportion of infections at $4.37 \%$, representing almost 2 million people. This would be scenario B in its variant without a vaccine (where the lockdown restrictions are gradually lifted starting on 30 January 2021). In the baseline scenario, the peak of the epidemic would fall on day 283 after its onset (i.e. around 11 December 2020) with the maximum proportion of infections on that day at $6.9 \%$.

In Poland, high maximum recovery rates $(42-50 \%)$ are observed in scenarios $B$ and $C$ without vaccination and with the vaccination of $25 \%$ of the population. Low recovery rates are observed in scenario A in its variants with vaccination, i.e. $20-27 \%$ of the population. Moreover, the fastest extinction of the epidemic can be observed in scenarios $\mathrm{C}$ and $\mathrm{B}$ with the vaccination of $75 \%$ of the population (July-August 2022). On the other hand, in the case of scenario A with the vaccination of $25 \%$ of the population, the epidemic would end in October 2023, and in scenario A without vaccination the epidemic would extend beyond the framework adopted in the simulations, i.e. 1,500 days (11 April 2024).

When analyzing the scenarios for the course of the epidemic in Ukraine, it is worth noting that the minimum timeframe for the epidemic to expire is two years. The epidemic would expire the soonest in the baseline scenario (day 774 of the epidemic). It would last the longest in scenario A - more than 1,500 days (variant 1 without a vaccine, the lockdown would be lifted when the proportion of infections falls below $50 \%$ of the empirical proportion on day 275). Out of all the variants, the epidemic would end the soonest in variant $\mathrm{C}_{3}$ - on day 782 of the epidemic $(90 \%$ of the population would be vaccinated and the lockdown restrictions would be lifted on 30 January 2021).

\section{References}

Atkeson, A. (2020). What will be the economic impact of COVID-19 in the US? Rough estimates of disease scenarios. NBER Working Paper, No. 26867. http:// www.nber.org/papers/w26867 (accessed January 30, 2021).

Bärwolff, G. (2020). Mathematical modeling and simulation of the COVID19 pandemic. Systems, 8(3), 1-12. https://doi.org/10.3390/systems8030024 (accessed January 30, 2021). 
Glavcom. (2020, May 11). V Ukrayini poslabyly karantyn: Shcho dozvoleno. https://glavcom.ua/news/v-ukrajini-poslabili-karantin-shcho-dozvoleno-679172 .html (accessed January 30, 2021).

Indexminfin. (2021, January 18). Koronavirus $v$ Ukrayini. https://index.minfin.com. ua/ua/reference/coronavirus/ukraine (accessed January 30, 2021).

Kermack, W. O., McKendrick, A. G. (1927). A contribution to the mathematical theory of epidemics, Proceedings of the Royal Society, Series A, 115, 700-721 (accessed January 30, 2021). https://royalsocietypublishing.org/doi/10.1098/ rspa.1927.0118

KMU. (2020a, March 11). Postanova Kabinetu Ministriv Ukrayiny No.211 vid 11 bereznya 2020 roku "Pro zapobihannya poshyrennyu na terytoriyi Ukrayiny koronavirusu COVID-19”. https://www.kmu.gov.ua/npas/pro-zapobigannyaposhim110320rennyu-na-teritoriyi-ukrayini-koronavirusu-covid-19 (accessed January 30, 2021).

KMU. (2020b, May 20). Uryad ukhvalyv rishennya pro poslablennya karantynu $z 22$ travnya. https://www.kmu.gov.ua/news/uryad-uhvaliv-rishennya-pro-posl ablennya-karantinu-z-22-travnya (accessed January 30, 2021).

KMU. (2020c, November 13). Uryad zaprovadyv karantyn vykhidnoho dnya (onovleno). https://www.kmu.gov.ua/news/uryad-zaprovadiv-karantin-vihidn ogo-dnya-onovleno(accessed January 30, 2021).

Lotnisko Chopina w Warszawie. (2020, January 25). Komunikat Lotniska Chopina. https://lotnisko-chopina.pl/pl/aktualnosci-i-wydarzenia/0/976/szczegoly.html (accessed January 30, 2021).

Medonet. (2020, February 29). NIZP-PZH przebadat 307 próbek pobranych od osób $z$ podejrzeniem zakażenia koronawirusem. https://www.medonet.pl/koronawir us/koronawirus-w-polsce,w-kierunku-koronawirusa-nizp-pzh-przebadal-307osob,artykul,78353052.html (accessed January 30, 2021).

MZSU. (2020, September 30). Uryad zminyv pravyla v'yizdu inozemtsiv v Ukrayinu na period diyi karantynu. https://mfa.gov.ua/news/uryad-zminiv-pravila-vyizduinozemciv-v-ukrayinu-na-period-diyi-karantinu (accessed January 30, 2021).

Portal miasta Gdańsk. (2020, October 23). Koronawirus - nowe obostrzenia. Nauka zdalna, zamknięte kawiarnie i restauracje. Co jeszcze? (accessed January 30, 2021). https://www.gdansk.pl/wiadomosci/koronawirus-nowe-obostrzenianauka-zdalna-zamkniete-kawiarnie-i-restauracje-co-jeszcze,a,181595

Serwis Rzeczypospolitej Polskiej. (2020a, March 21). Rozporzadzenie Ministra Zdrowia zdnia 20 marca 2020 r.wsprawie ogtoszenia na obszarze Rzeczypospolitej Polskiej stanu epidemii. https:/www.gov.pl/web/rpa/rozporzadzenie-ministra -zdrowia-z-dnia-20-marca-2020-r-w-sprawie-ogloszenia-na-obszarze -rzeczypospolitej-polskiej-stanu-epidemii (accessed January 30, 2021).

Serwis Rzeczypospolitej Polskiej. (2020b, April 16). Nowa normalność: Etapy znoszenia ograniczeń zwiazanych z COVID-19. https://www.gov.pl/web/ koronawirus/nowa-normalnosc-etapy (accessed January 30, 2021).

Serwis Rzeczypospolitej Polskiej. (2021, January 20). Raportzakażeń koronawirusem. https:/www.gov.pl/web/koronawirus/wykaz-zarazen-koronawirusem-sars-cov255 (accessed January 30, 2021).

Ukrinform. (2020, February 25). Sekretar RNBO proviv naradu shchodo sytuatsiyi $z$ koronavirusom. https://www.ukrinform.ua/rubric-polytics/2884185-sekretarrnbo-proviv-naradu-sodo-situacii-z-koronavirusom.html (accessed January 30, 2021). 


\section{Pawet Dykas et al.}

Unian. (2020, June 13). Ukrayina hotuyet'sya do vidnovlennya aviaspoluchennya: Kudy ta za yakykh umov zmozhut' litaty ukrayintsi (video). https://www.unian. ua/tourism/news / kudi - mozhna-litati -ukrajincyam-vidnovlennyaaviaspoluchennya-novini-11035208.html (accessed January 30, 2021).

VRU. (2020, April 2). Postanova Kabinetu Ministriv Ukrayiny vid 2 kvitnya 2020 r. No. 255 Kyyiv Pro vnesennya zmin do postanovy Kabinetu Ministriv Ukrayiny vid 11 bereznya 2020 r. No. 211. https://zakon.rada.gov.ua/laws/show/2552020-\%D0\%BF\#Text (accessed January 30, 2021). 